\title{
Novel Phage-Derived Depolymerase with Activity against Proteus mirabilis Biofilms
}

\author{
Cormac J. Rice, Stephen A. Kelly ${ }^{\dagger}$, Seamus C. O’Brien ${ }^{\dagger}$, Erinn M. Melaugh, Jan C. B. Ganacias, Zheng Hua Chai, \\ Brendan F. Gilmore and Timofey Skvortsov *(1)
}

check for updates

Citation: Rice, C.J.; Kelly, S.A.; O'Brien, S.C.; Melaugh, E.M.; Ganacias, J.C.B.; Chai, Z.H.; Gilmore, B.F.; Skvortsov, T. Novel PhageDerived Depolymerase with Activity against Proteus mirabilis Biofilms. Microorganisms 2021, 9, 2172. https://doi.org/10.3390/ microorganisms 9102172

Academic Editors: Karen D. Weynberg and Sabrina Green

Received: 28 September 2021 Accepted: 15 October 2021 Published: 19 October 2021

Publisher's Note: MDPI stays neutral with regard to jurisdictional claims in published maps and institutional affiliations.

Copyright: (c) 2021 by the authors. Licensee MDPI, Basel, Switzerland. This article is an open access article distributed under the terms and conditions of the Creative Commons Attribution (CC BY) license (https:/ / creativecommons.org/licenses/by/ $4.0 /)$.
School of Pharmacy, Queen's University Belfast, Belfast BT9 7BL, UK; crice41@qub.ac.uk (C.J.R.); Stephen.Kelly@qub.ac.uk (S.A.K.); Seamus.Obrien@qub.ac.uk (S.C.O.); Emelaugh01@qub.ac.uk (E.M.M.); Jganacias01@qub.ac.uk (J.C.B.G.); zchai01@qub.ac.uk (Z.H.C.); b.gilmore@qub.ac.uk (B.F.G.)

* Correspondence: t.skvortsov@qub.ac.uk; Tel.: +44-28-9097-2029

+ These authors contributed equally to this work.

\begin{abstract}
The adherence of Proteus mirabilis to the surface of urinary catheters leads to colonization and eventual blockage of the catheter lumen by unique crystalline biofilms produced by these opportunistic pathogens, making P. mirabilis one of the leading causes of catheter-associated urinary tract infections. The Proteus biofilms reduce efficiency of antibiotic-based treatment, which in turn increases the risk of antibiotic resistance development. Bacteriophages and their enzymes have recently become investigated as alternative treatment options. In this study, a novel Proteus bacteriophage (vB_PmiS_PM-CJR) was isolated from an environmental sample and fully characterized. The phage displayed depolymerase activity and the subsequent genome analysis revealed the presence of a pectate lyase domain in its tail spike protein. The protein was heterologously expressed and purified; the ability of the purified tail spike to degrade Proteus biofilms was tested. We showed that the application of the tail spike protein was able to reduce the adherence of bacterial biofilm to plastic pegs in a MBEC (minimum biofilm eradication concentration) assay and improve the survival of Galleria mellonella larvae infected with Proteus mirabilis. Our study is the first to successfully isolate and characterize a biofilm depolymerase from a Proteus phage, demonstrating the potential of this group of enzymes in treatment of Proteus infections.
\end{abstract}

Keywords: Proteus; bacteriophage; urinary tract infections (UTIs); depolymerases; antibiotic resistance; pectate lyase; biofilms

\section{Introduction}

Proteus mirabilis is a Gram-negative, opportunistically pathogenic bacterium which is widespread in natural and built environments and commonly present in gastrointestinal tracts of healthy humans. One of the distinguishing features of P. mirabilis is its swarming motility, resulting in formation of characteristic "bull's-eye" patterns when grown on solid media. This is the result of sequential rounds of formation of elongated swarming cells, capable of flagella-assisted migration across surfaces, followed by deconsolidation into rod-shaped swimmer cells. Upon coming into contact with a surface and initial attachment, presumably facilitated by multiple types of fimbriae produced by $P$. mirabilis cells, the microorganisms undergo a drastic morphological change, elongating up to 50 times, and start secreting polysaccharides enabling attachment and colonization of surfaces in the form of biofilms. The readiness with which the bacterium forms biofilms on a variety of abiotic surfaces in combination with its ability to rapidly spread by swarming makes it a clinically important pathogen, capable of colonizing a variety of indwelling medical devices, including urinary catheters. It has been estimated that $P$. mirabilis causes between 1 and $10 \%$ of all urinary tract infections (UTIs) and is responsible for up to $44 \%$ of all catheter-associated urinary tract infections (CAUTIs) in the US [1]. One of the factors contributing to efficient urinary catheter colonization by P. mirabilis and resulting in severe 
UTIs is the production of a nickel containing metalloenzyme urease. Urease facilitates the hydrolysis of urea in urine, resulting in the formation of apatite and/or struvite crystals [2]. These crystals become embedded into the polymeric matrix of Proteus biofilms where they accumulate and grow, thus being a major factor in the blockage of urinary catheters. The obstructions created by crystalline biofilms prevent the free flow of urine and promote the ascending spread of infection, which ultimately leads to bacteriuria, pyelonephritis, bacteremia, and, in some cases, urosepsis and death. The socio-economic impact of CAUTIs, including those caused by Proteus, is significant, costing the National Health Service (NHS) between GBP 1.5 and 2.25 billion each year. Thus, a novel means of preventing and controlling crystalline biofilm formation is imperative [3].

In light of the ongoing antibiotics crisis and increasing prevalence of multidrug resistant strains among clinical isolates of Proteus mirabilis and related species, alternative approaches for control and management of CAUTIs are being investigated [4]. Among some of the most promising approaches for biofilm control is the use of bacteriophages. Bacteriophages are bacterial viruses that are the natural predators of bacteria and have been used in Eastern Europe and the former Soviet Union since before the discovery of antibiotics; after a long period of disuse, phage therapy has recently gained increased interest in Western medicine [5]. Phages act by binding to a receptor on the host cell surface before injecting their genetic material and replicating to produce progeny. The progeny eventually lyses the host cell and the cycle is repeated. The use of phages and their products as an alternative to traditional antibiotics has several advantages including high specificity and efficacy, low immunogenicity, and production costs [6,7]. Despite that, as both phage and their respective host are in a constant evolutionary arms race, the continuous isolation and characterization of novel bacteriophages is imperative for establishing an effective antimicrobial arsenal for treating a plethora of multidrug resistant infections $[8,9]$.

Phages are known to encode several enzymes of antimicrobial interest. Purification and characterization of phage derived antimicrobials allows for alternative phage-based therapeutics to be used in situations where the whole phage may not be as effective due to issues such as host specificity or resistance. In particular, the development of resistance appears to be happening at a significantly decreased rate when phage-derived enzymes are used instead of bacteriophages [10]. The most well studied of such enzymes are endolysins that degrade the peptidoglycan of the bacterial host's cell wall; these enzymes have previously proven effective in controlling bacterial infections and a number are used commercially, e.g., phage enzyme preparations produced by Armata, Micreos, and Intralytix [11,12]. Another group of phage proteins with a significant therapeutic potential are polysaccharide depolymerases [13]. The majority of bacteriophage polysaccharide depolymerases are associated with the virion surface, most often encoded as a part of tail fibers and other structural proteins. Depolymerases are thought to act on either the capsular polysaccharide (CPS), the exopolysaccharides (EPS), or the lipopolysaccharides (LPS) of their host bacterium, cleaving these polymeric substances produced by the host cell and exposing the cell surface receptors necessary for binding, thus facilitating the phage infection (Figure 1). Due to the important role played by CPS, EPS, and LPS in the formation of biofilms, depolymerase enzymes are now being investigated in terms of preventing and treating biofilm related infections. The main advantage of phage depolymerases is their mode of action. Being non-lytic enzymes, depolymerases act as antivirulence agents, decreasing the severity of infection and helping the immune system of the host to clear the infection. Despite these attractive qualities, the research into therapeutic use of phage depolymerases so far has been mostly focused on a few bacterial species for which the critical importance of capsular polysaccharides as virulence factors has been well established, particularly in Klebsiella pneumoniae, Acinetobacter baumannii, and Escherichia coli [14-16]. As a result of their ability to prevent the formation and degrade established biofilms, depolymerase enzymes are now being explored as potential antimicrobials for the treatment of biofilm related infections. In this study, we isolated and characterized a novel lytic Proteus mirabilis phage vB_PmiS_PM-CJR capable of biofilm matrix degradation, 
identified a putative pectate lyase domain in its tail spike, and produced it as a recombinant protein. The ability of the recombinant depolymerase to reduce the formation of Proteus mirabilis biofilms in vitro and improve survival in Galleria mellonella infection (the greater wax moth larvae model often used to study host-pathogen interactions) was demonstrated experimentally. To the best of our knowledge, this is the first publication describing a functional depolymerase from a Proteus phage.

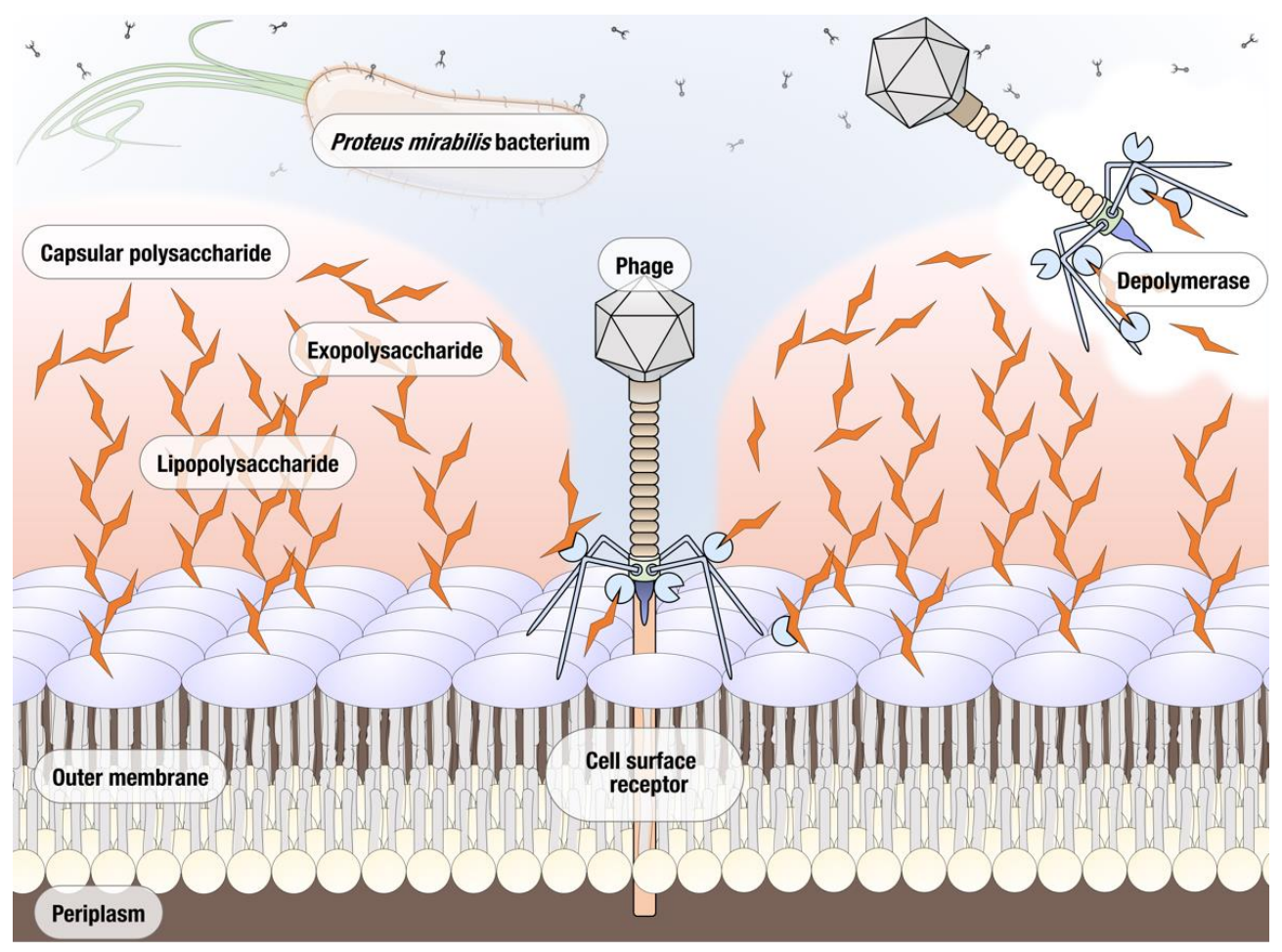

Figure 1. Potential polymeric targets for polysaccharide depolymerases of Proteus bacteriophages.

\section{Materials and Methods}

\subsection{Bacterial Strains and Cultivation Media Used in the Study}

Proteus mirabilis strain BB2000 [17] was used for isolation and propagation of bacteriophages. To determine the host range of isolated phages, 17 different clinically isolated and reference strains of Proteus mirabilis were used, in addition to Proteus vulgaris UM266 and Proteus penneri NCTC 12737 (see the Results section). All bacterial cultures were grown in LB broth (LBB) (Invitrogen, Paisley, UK).

\subsection{Enrichment Cultures for Isolation of Proteus Bacteriophages}

Mud samples collected from Shaw's Bridge parkland region in Northern Ireland, UK were used for isolation of Proteus bacteriophages. For this, $1 \mathrm{~mL}$ of overnight cultures of several Proteus strains was inoculated with $0.5 \mathrm{~g}$ of the mud sample in addition to $10 \mathrm{~mL}$ of $10 \times$ strength LB growth media (Invitrogen, Paisley, UK) and $35 \mathrm{~mL}$ of autoclaved ultrapure water. The mixture was incubated for $3-5$ days at $37^{\circ} \mathrm{C}, 100 \mathrm{rpm}$ to allow for the amplification of the phages. After the set period of time, the enrichment cultures were centrifuged at $4000 \times g$ for 5-10 min and the supernatant filtered through a MillexGS $0.22 \mu \mathrm{m}$ syringe filter (Millipore, Burlington, MA, USA). Spot tests of the enriched filtrates were performed against different strains of Proteus using the spot test overlay technique [18]. Briefly, $250 \mu \mathrm{L}$ of bacterial overnight culture was inoculated into 5-6 $\mathrm{mL}$ of top agar (Invitrogen, Paisley, UK) (0.75\% agar plus the other LB components) and quickly swirled before being poured on top of LB agar (Invitrogen, Paisley, UK) plates and left to set for $30 \mathrm{~min}$. After the setting period, $10 \mu \mathrm{L}$ of enriched $0.22 \mu \mathrm{m}$ filtrate was spotted onto 
the plates and allowed to dry before being incubated at $37^{\circ} \mathrm{C}$ overnight. The next day, phage spots were visualized, and their morphology and diameter recorded.

\subsection{Plaque Assays and Isolation of Phage vB_PmiS_PM-CJR}

The clear zone produced on P. mirabilis BB2000 lawn was picked and propagated on the respective host strain. Briefly, using a $10 \mu \mathrm{L}$ sterile pipette tip, the point of the tip was touched against the center of the phage spot ensuring to avoid contact with the surrounding bacteria. The tip was then placed into $90 \mu \mathrm{L}$ of sterile SM (phage) buffer [19] and consequently serially diluted with SM buffer 1 in 10 until a final dilution of $10^{-8}$ was achieved. To propagate phages, a plaque assay was performed, in which $10 \mu \mathrm{L}$ of phage at different concentrations was inoculated with $250 \mu \mathrm{L}$ of an overnight culture of the respective bacterial culture. The mixture was shaken gently by swirling before being left for $10 \mathrm{~min}$ to allow for phage adsorption to the bacterial cells. After the adsorption period, a top agar plaque assay was performed.

\subsection{One-Step Growth Curve Assay}

The one-step growth curve was performed as described elsewhere with small adjustments [20]. Briefly, a P. mirabilis BB2000 culture was incubated to early exponential phase and the bacterial culture adjusted to $1 \times 10^{8}$ colony forming units (CFU) $/ \mathrm{mL}$. Then, $1 \mathrm{~mL}$ of the bacterial cell culture was centrifuged at $6000 \times \mathrm{g}$ for $10 \mathrm{~min}$ and the pellet resuspended in $0.1 \mathrm{~mL}$ of $1 \times 10^{6}$ plaque forming units (PFU) / $\mathrm{mL}$ of phage vB_PmiS_PM-CJR (MOI 0.001). The mixture was incubated at $37^{\circ} \mathrm{C}$ for $15 \mathrm{~min}$ before being centrifuged twice at $5000 \times g$ for $3 \mathrm{~min}$ and washed with LBB to remove any unabsorbed phage from the mixture. The pellet was then resuspended in $9.9 \mathrm{~mL}$ of sterile LBB and the mixture incubated at $37^{\circ} \mathrm{C}$ for $70 \mathrm{~min}$ at $250 \mathrm{rpm}$. Aliquots of the mixture were taken firstly every $5 \mathrm{~min}$ up to $20 \mathrm{~min}$ and then every $10 \mathrm{~min}$ thereafter. The aliquots taken were serially diluted and subject to a top agar plaque assay before the phage titer was determined and the burst size calculated. The burst size, expressed in plaque-forming units per infected cell (PFU/cell), was calculated as the average number of phage particles released between the end of the latent period and stabilization (plateauing) of the phage titer, and normalized by the titer of the bacterial culture.

\subsection{Host Adsorption Assay}

Host adsorption assay was carried out as described elsewhere [18,21]. Briefly, $950 \mu \mathrm{L}$ of LB media and $60 \mu \mathrm{L}$ of chloroform (Merck, Watford, UK) were added to 12 capped $13 \times 100 \mathrm{~mm}$ sterile test tubes and chilled on ice for $10 \mathrm{~min}$. A logarithmic phase culture of the respective host culture was diluted to give an $\mathrm{OD}_{600}$ of 0.2 . To one flask was added $9 \mathrm{~mL}$ of the bacterial culture and to the other $9 \mathrm{~mL}$ sterile media. Both flasks were incubated at $48^{\circ} \mathrm{C}$ for $5 \mathrm{~min}$ before $1 \mathrm{~mL}$ of phage suspension pre-warmed to $37^{\circ} \mathrm{C}$ was added to each and a timer started. At 1 min intervals a $100 \mu \mathrm{L}$ aliquot was taken and added to the chilled tubes. Finally, the tubes were vortexed vigorously and $100 \mu \mathrm{L}$ samples taken and added to top agar with $250 \mu \mathrm{L}$ host cells and a plaque assay performed. The plates were incubated at $37^{\circ} \mathrm{C}$ until the appearance of plaques, after which the plaques were counted.

\subsection{Host Range Determination of vB_PmiS_PM-CJR}

The host range of the phage vB_PmiS_PM-CJR was determined via a spot assay against a range of Proteus spp. LB agar plates were overlaid with 5-6 $\mathrm{mL}$ of top agar containing $350 \mu \mathrm{L}$ of the respective strain. Once dried, $10 \mu \mathrm{L}$ of phage lysate was spotted on to the plate and allowed to dry before being placed in a $37^{\circ} \mathrm{C}$ incubator for $18 \mathrm{~h}$. After the incubation period, spots were observed on the bacterial lawns susceptible to vB_PmiS_PM-CJR infection. 


\subsection{Electron Microscopy}

Transmission electron microscopy was performed by aseptically transferring $100 \mu \mathrm{L}$ of high titer phage lysate into a $1.5 \mathrm{~mL}$ tube. The lysate was centrifuged at $4000 \times g$ for $22 \mathrm{~min}$ before being resuspended in $100 \mu \mathrm{L}$ of sterile phage buffer. Using sterile EM forceps, a fresh EM grid (Ted Pella Inc., Redding, CA, USA) was placed on a clean KIM wipe with the dark shiny side facing up. Following this, $5 \mu \mathrm{L}$ of phage lysate was added to the grid and allowed to sit for $8 \mathrm{~min}$. The grid was rinsed at a $45^{\circ}$ angle with $60 \mu \mathrm{L}$ of ultrapure autoclaved water. Any excess water was allowed to drain off. Five microliters of $1 \%$ uranyl acetate were added to the grid and immediately removed after to prevent overstaining. The grid was allowed to dry overnight before being imaged on a JEOL JEM-1400 Plus Transmission Electron Microscope (JEOL Ltd., Tokyo, Japan).

\subsection{Thermal Stability Test}

To determine the thermal stability of phage vB_PmiS_PM-CJR, $500 \mu \mathrm{L}$ of bacteriophage lysate with the initial titer of $1 \times 10^{10} \mathrm{PFU} / \mathrm{mL}$ was incubated at the set temperatures (in the range from 40 to $100{ }^{\circ} \mathrm{C}$ ) for an allocated period of time of $1 \mathrm{~h}$. After the said period of time, the phage suspension was subject to a top agar overlay assay. The plates were incubated at $37^{\circ} \mathrm{C}$ overnight and the plaques observed the next day were counted and quantified. Experiments were carried out in triplicate and the average number of plaques were used to determine the titer.

\subsection{Extraction of Phage DNA}

Phage DNA was extracted as follows. The lysate $(500 \mu \mathrm{L})$ was treated with $1.25 \mu \mathrm{L}$ of DNaseI (Sigma, Gillingham, UK) $(20 \mathrm{mg} / \mathrm{mL})$ and incubated at $4{ }^{\circ} \mathrm{C}$ overnight. The next day $1.25 \mu \mathrm{L}$ of proteinase K (Sigma, Gillingham, UK) $(20 \mathrm{mg} / \mathrm{mL})$ was added to it along with $25 \mu \mathrm{L}$ of $10 \%$ SDS and $20 \mu \mathrm{L}$ of $0.5 \mathrm{M}$ EDTA pH 8.0 (Merck, Watford, UK). The contents were mixed and incubated at $60^{\circ} \mathrm{C}$ for $1 \mathrm{~h}$. Once cooled, an equal volume of phenol:chloroform:isoamyl alcohol mixture (25:24:1 v/v) (Sigma, Gillingham, UK) was added and inverted several times before being centrifuged using an Eppendorf 5430 centrifuge (Eppendorf UK, Stevenage, UK) at $6000 \times g$ for $5 \mathrm{~min}$ at room temperature. Using a wide bore tip, the aqueous phase was transferred to a fresh $2 \mathrm{~mL}$ tube and the process repeated. The aqueous phase was once more transferred to a new tube where an equal volume of chloroform was added, after which the contents of the tube were again mixed by vortexing and centrifuged. The upper (aquatic) phase was transferred to a new tube and the previous step repeated once more. A 1/10 volume of 3M NaOAc (Thermo Fisher Scientific, Loughborough, UK)) ( $\mathrm{pH} 7.5$ ) was added along with 2.5 volumes of ice-cold molecular grade 95\% ethanol (Sigma, Gillingham, UK) and mixed well, then incubated on ice for $30 \mathrm{~min}$. The mixture was centrifuged at maximum speed for $20 \mathrm{~min}$ and the supernatant discarded, after which the DNA pellet was washed with an equal volume of $70 \%$ ethanol and reprecipitated by centrifugation for a further $2 \mathrm{~min}$; this step was repeated one more time. The supernatant was discarded, and the remaining trace amounts of ethanol were allowed to evaporate before eluting the DNA in $30 \mu \mathrm{L}$ of nuclease free water.

\subsection{Phage vB_PmiS_PM-CJR Genome Seqeuncing, Assembly and Annotation}

BGISEQ-500 WGS sequencing libraries were prepared and phage DNA was sequenced at BGI Hong Kong using the BGISEQ-500 sequencing platform (DNBSEQ technology; BGI, Hong Kong, China). Raw reads (150PE) were trimmed using Sickle v1.33 [22]. The processed reads were assembled using Unicycler v0.4.8, running in the conservative mode [23]. After that, PhageTerm v1.0.12 was used to determine the packaging type and predict phage termini [24]. The phage genome sequence was realigned in order to make the start of the sequence correspond with the predicted packaging site. Open reading frames were then predicted with Prodigal v3.6.3, after which the assembled phage genome was manually annotated in the Artemis genome browser tool (v18.1.0) [25,26], with the help of MultiPhATE (v2.1) and online versions of NCBI Blast (https:/ / blast.ncbi.nlm.nih.gov/Blast.cgi; 
accessed on 21 July 2021), HHPred (https:/ / toolkit.tuebingen.mpg.de/tools/hhpred; accessed on 21 July 2021), PhANNs (https://edwards.sdsu.edu/phanns; accessed on 21 July 2021), and HMMER (https://www.ebi.ac.uk/Tools/hmmer/; accessed on 21 July 2021) [27-31]. The putative tail spike protein of PmiS_PM-CJR was additionally analyzed with online versions of I-TASSER (https: / / zhanggroup.org/I-TASSER/; accessed on 1 July 2021), NCBI CDD (https://www.ncbi.nlm.nih.gov/Structure/cdd/wrpsb.cgi; accessed on 22 July 2021), and InterProScan (https:/ /www.ebi.ac.uk/interpro/search/sequence/; accessed on 22 July 2021) [32-34]. Protein model visualization was performed with UCSF ChimeraX software (v1.2) [35]. Structural alignments were carried out using mTM-align ( https:/ /yanglab.nankai.edu.cn/mTM-align/; accessed on 22 July 2021) [36].

\subsection{Whole-Genome Comparison and Phylogenetic Analysis}

Easyfig v2.2.2 [37] was used to generate and visualize whole-genome comparisons of vB_PmiS_PM-CJR and most closely related phage genomes in the NCBI Genbank (identified as having at least $90 \%$ nucleotide sequence identity with at least $80 \%$ query coverage). Intergenomic similarities were calculated with the online version of VIRIDIC (http://rhea.icbm.uni-oldenburg.de/VIRIDIC/; accessed on 7 September 2021) using default parameters [38]. Amino acid sequences of the terminase large subunit (TerL) and major capsid protein (MCP) were used for phylogenetic characterization of vB_PmiS_PMCJR. A BLASTp search against viral proteins available in NCBI RefSeq at the moment of writing was conducted and only proteins with sufficiently high similarity (e-value $\leq 1 \times 10^{-10}$; percent identity $\geq 25 \%$ ) to TerL and MCP of vB_PmiS_PM-CJR were retained for subsequent analyses. Multiple alignments of the amino acid sequences of TerL and MCP were generated in MAFFT v7.487 using L-INS-I settings, and TrimAl v1.4 was used for automated alignment trimming [39,40]. The inference of phylogenies was then carried out using IQ-Tree v2.1 [41], which was allowed to compute the optimal protein evolution model to be used. Visualization of the resulting tree files was subsequently performed with FigTree v 1.4.4 [42].

\subsection{Phage vB_PmiS_PM-CJR Cloning and Expression of Tail Spike Protien}

The gene construct containing the full tail spike protein gene was synthesized by Genscript (Leiden, the Netherlands). The synthesized gene was supplied in a pET-28a(+) plasmid vector (Novagen, Madison, WI, USA) cloned using BamHI and HindIII restriction sites. The plasmid construct was resolubilized to a concentration of $5 \mu \mathrm{g} / \mathrm{mL}$ in nuclease free water and $5 \mu \mathrm{L}$ of this solution was used to transform Escherichia coli KRX cells (Promega, Madison, WI, USA, cat. no. L3002) using heat shock transformation. Briefly, $5 \mu \mathrm{L}$ of the plasmid was added to $50 \mu \mathrm{L}$ of KRX competent cells and left on ice for $30 \mathrm{~min}$. An alternative pET-28a(+) vector with a different size gene and $5 \mu \mathrm{L}$ of nuclease free water were used as positive and negative controls, respectively. The tubes were placed in a water bath at $42{ }^{\circ} \mathrm{C}$ for $1 \mathrm{~min}$ before returning to ice for $2 \mathrm{~min}$. After that, $300 \mu \mathrm{L}$ of SOC media (Thermo Fisher Scientific, Loughborough, UK) was added and the culture incubated at $37^{\circ} \mathrm{C}$ for $1 \mathrm{~h}$, followed by overnight incubation at $37^{\circ} \mathrm{C}$ on pre-warmed LB agar plates containing $50 \mathrm{\mu g} / \mathrm{mL}$ kanamycin (Merck, Watford, UK).

\subsection{Tail Spike Protein Expression and Purification}

A single colony from transformation plates was used to inoculate LBB containing kanamycin (50 $\mathrm{\mu g} / \mathrm{mL}$ ) (Merck, Watford, UK) and 0.4\% glucose (Merck, Watford, UK), and this was allowed to incubate at $37^{\circ} \mathrm{C}$ overnight. Overnight starter cultures were diluted 1:100 into fresh LBB containing kanamycin $(50 \mu \mathrm{g} / \mathrm{mL})$ and grown at $37^{\circ} \mathrm{C}$ at $200 \mathrm{rpm}$ until an optical density $\left(\mathrm{OD}_{600}\right)$ of 0.4 was achieved. The culture was then incubated at $25^{\circ} \mathrm{C}$ until the $\mathrm{OD}_{600}$ reached 0.5 , at which point $1 \mu \mathrm{L}$ of $20 \%$ rhamnose (Merck, Watford, UK) was added along with IPTG (Merck, Watford, UK) to a final concentration of $1 \mathrm{mM}$. Cultures were allowed to incubate overnight at $25^{\circ} \mathrm{C}$ before harvesting the cells via centrifugation 
at $10,000 \times g$ for $5 \mathrm{~min}$. Cells were lysed via sonication on ice in sterile $1 \times$ Dulbecco's phosphate-buffered saline (PBS) (BR0014, Oxoid, Basingstoke, UK).

Clarified by centrifugation (5000 rpm for $15 \mathrm{~min}$ ) cell-free extract was purified by immobilized metal affinity chromatography (IMAC) using the N-terminal $6 \times$ His-tag encoded by the pET-28a(+) vector. An ÄKTA Prime Plus Liquid Chromatography System (GE Healthcare, Chicago, IL, USA) was used to load the clarate on a HisTrap HP $1 \mathrm{~mL}$ column (both GE Healthcare Life Sciences, Little Chalfont, UK) at a rate of $1 \mathrm{~mL} / \mathrm{min}$. This was washed using buffer containing $50 \mathrm{mM} \mathrm{NaH}_{2} \mathrm{PO}_{4}, 300 \mathrm{mM} \mathrm{NaCl}$, and $20 \mathrm{mM}$ imidazole, made up to $1 \mathrm{~L}$ with $\mathrm{dH}_{2} \mathrm{O}$ and adjusted to $\mathrm{pH} 8.0$ with $\mathrm{NaOH}$. Purified protein was eluted in $1 \mathrm{~mL}$ fractions using buffer containing $50 \mathrm{mM} \mathrm{NaH}_{2} \mathrm{PO}_{4}, 300 \mathrm{mM} \mathrm{NaCl}$, and $250 \mathrm{mM}$ imidazole made up to $1 \mathrm{~L}$ with $\mathrm{dH}_{2} \mathrm{O}$ and adjusted to $\mathrm{pH} 8.0$ with $\mathrm{NaOH}$.

\subsection{SDS-PAGE}

Five microliters of $5 \times$ SDS-PAGE denaturing Laemmli buffer $(20 \% 1.5 \mathrm{M}$ Tris- $\mathrm{HCl}$ $\mathrm{pH} 6.8,50 \%$ glycerol, $25 \% \beta$-mercaptoethanol, $10 \%$ SDS $(w / v)$, and $5 \%$ of $1 \%$ bromophenol blue) was added to $20 \mu \mathrm{L}$ of respective sample and heat treated at $95^{\circ} \mathrm{C}$ for $10 \mathrm{~min}$. Ten microliters of each denatured sample was loaded into an Invitrogen NuPAGE 4-12\% BisTris gel ( $1.5 \times 10 \mathrm{~mm}$ well; Invitrogen, Carlsbad, CA, USA) along with $5 \mu \mathrm{L}$ of SeeBlue Plus2 Pre-stained Protein Standard (Invitrogen, Carlsbad, CA, USA) and run at $200 \mathrm{~V}$ for approximately $1 \mathrm{~h}$, using Novex $1 \times$ MES SDS (Invitrogen, Carlsbad, CA, USA) as running buffer. The gel was stained using Coomassie blue staining solution ( $2 \%$ Coomassie blue R-250 (w/v), $42.5 \%$ water, $50 \%$ ethanol and $7.5 \%$ acetic acid). The gel was then placed in de-stain solution $\left(87.5 \% \mathrm{ddH}_{2} \mathrm{O}, 5 \%\right.$ methanol and $7.5 \%$ acetic acid) and washed three times with water. The gel was imaged using G:BOX Chemi XRQ imager (Syngene, Cambridge, UK).

\subsection{Reverse Phase High Performance Liquid Chromatography (RP-HPLC) for Tail Spike Purity Analysis}

The purity of the recombinant tail spike protein was determined using an Agilent 1260 Infinity (Agilent Technologies, Santa Clara, CA, USA) RP-HPLC system. Ten microliters of the purified tail spike $(891 \mathrm{ng} / \mu \mathrm{L})$ was loaded onto a Kinetex C18 column $(50 \times 4.6 \mathrm{~mm}$, $5 \mu \mathrm{m}, 100 \AA$ A; Phenomenex, Macclesfield, UK) and analyzed at room temperature. Two mobile phases were used: $0.1 \%$ trifluoroacetic acid (TFA) in water (mobile phase A) and $0.1 \%$ TFA in acetonitrile (mobile phase B). The mobile phase gradient used was $5 \%$ to $95 \%$ $\mathrm{B}$ in $30 \mathrm{~min}$, with a flow rate of $1 \mathrm{~mL} / \mathrm{min}$. Protein elution was continuously monitored by measuring the absorbance at $254 \mathrm{~nm}$ wavelength.

\subsection{Assessing the Activity of vB_PmiS_PM-CJR's Recombinant Tail Spike Protein}

To assess the ability of the protein to degrade the polysaccharide matrix produced by Proteus, a dilution series of the purified tail spike protein prepared in sterile $1 \times$ PBS buffer was used in a spot test and compared to serial dilutions of vB_PmiS_PM-CJR, also diluted in sterile $1 \times$ PBS. A top agar spot test on a lawn of P. mirabilis BB2000 was performed before incubating the plates overnight at $37^{\circ} \mathrm{C}$. Spot zones were observed the next day and compared.

\subsection{P. mirabilis MBEC Peg Adsorption Assay}

The MBEC (Innovotech Inc, Edmonton, AB, Canada) adherence assay was performed by adjusting the $\mathrm{OD}_{600}$ of an overnight culture of P. mirabilis BB2000 to 0.1 in sterile LBB media. The optical density was adjusted using LB broth with tail spike protein added to a final concentration of $100 \mu \mathrm{g} / \mathrm{mL}$. After that, $150 \mu \mathrm{L}$ of culture was then added to the rows of the MBEC plate. The MBEC lid with pegs protruding from the surface was added to the bacterial culture wells supplemented with tail spike protein and placed into a plastic container with a damp lint free cloth. The container with the MBEC plate was incubated at $37^{\circ} \mathrm{C}$ for $4 \mathrm{~h}$ before colony counts were performed. Control wells of LBB and a vehicle control (50 mM Tris- $\mathrm{HCl} \mathrm{pH} 8.0$ diluted into sterile LBB) were added to the MBEC plate. 
Phage vB_PmiS_PM-CJR solution was used for comparison (final titer-1 $\times 10^{6} \mathrm{PFU} / \mathrm{mL}$ ). The collected data was analyzed using Prism 7 (GraphPad Software, San Diego, CA, USA). One-way ANOVA with Tukey's post-hoc test was used for comparison of treatment groups.

\subsection{Galleria mellonella Survivability Study}

Fresh Galleria mellonella (greater wax moth) larvae were used for this study. Larvae were injected with $20 \mu \mathrm{L}$ of an overnight culture P. mirabilis BB2000 at a range of different titers diluted down using sterile $1 \times$ PBS. Using sterile 29-gauge insulin needles, $20 \mu \mathrm{L}$ of the bacteria was injected into the lower left anal end proleg and the larvae placed in a sterile Petri dish. For treatment conditions, $20 \mu \mathrm{L}$ of the treatment solution to be used was immediately injected into the lower right proleg at the anal end of the larva after injection of the bacteria. Treatment of both phage and recombinant tail spike protein were used. Phage vB_PmiS_PM-CJR was used at a titer of $1 \times 10^{7} \mathrm{PFU} / \mathrm{mL}$. The tail spike protein was administered at a concentration of $100 \mu \mathrm{g} / \mathrm{mL}$. Controls of $1 \times$ PBS were used to ensure the correct injecting technique was used. Larvae were incubated at $37^{\circ} \mathrm{C}$ and survivability recorded at 24 and $48 \mathrm{~h}$ time points. Experiments were carried out using 10 replicates for each condition and repeated three times. Survivability was determined as the percentage (\%) of G. mellonella alive and motile after the defined incubation periods.

\section{Results}

\subsection{Biological Characteristics}

\subsubsection{Phage Isolation and Purification}

We performed the isolation of Proteus bacteriophages from a number of environmental samples collected in Northern Ireland (mud samples collected from the vicinity of the Shaw's Bridge on River Lagan), using Proteus mirabilis BB2000 as a host strain. Initial identification of the presence of phage activity was conducted using spot assays. The plaque assay conducted with the material from one of the phage-positive samples led to the formation of medium-sized (1-3 mm) clear plaques on a lawn of P. mirabilis BB2000, surrounded by semi-transparent haloes (Figure 2a, top). The halo region around each plaque is indicative of phage encoded depolymerase enzyme activity and the expansion of the halo region after $48 \mathrm{~h}$, as seen in Figure 2a, bottom, is also characteristic of phage depolymerases. The material from one of the plaques was used for further phage purification by three sequential plaque assays. The resulting phage stock suspension was prepared in SM buffer and stored at $+4{ }^{\circ} \mathrm{C}$.

\subsubsection{Electron Microscopy}

The morphology of phage particles was examined by transmission electron microscopy (TEM). Based on the appearance, the phage could be described as a siphovirus, with viral particles having the icosahedral capsid $(76 \mathrm{~nm}$ in diameter) and a long, flexible tail, approximately $180 \mathrm{~nm}$ long (Figure $2 \mathrm{~b}$ ). Using the recommended phage naming guidelines [43], the newly isolated phage was named vB_PmiS_PM-CJR.

\subsubsection{Infection Kinetics}

Host adsorption assay was used to assess the rate of attachment of phage vB_PmiS_PMCJR to its host cell surface receptors. The analysis of the data obtained showed that over $90 \%$ of the phage particles adsorbed to the host cells within first $5 \mathrm{~min}$ after the phage addition (Figure 3a). The one-step growth curve analysis was used to characterize the life cycle of vB_PmiS_PM-CJR and assess its growth kinetics, including the latent period and burst size (Figure 3b). The latent period of phage vB_PmiS_PM-CJR was estimated to be approximately $10 \mathrm{~min}$, which can be considered average in comparison to other Proteus phages [44-46], although direct comparison is difficult due to substantial methodological differences between studies. The growth cycle appears to be complete in approximately 30-35 $\mathrm{min}$ as the phage titer begins to plateau after this time period. The burst size of the phage was determined to be approximately $30 \mathrm{PFU} /$ cell. 


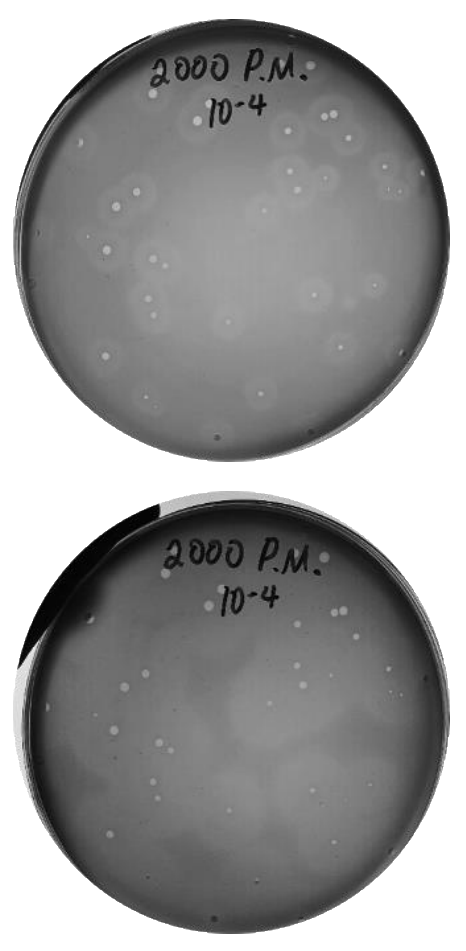

(a)
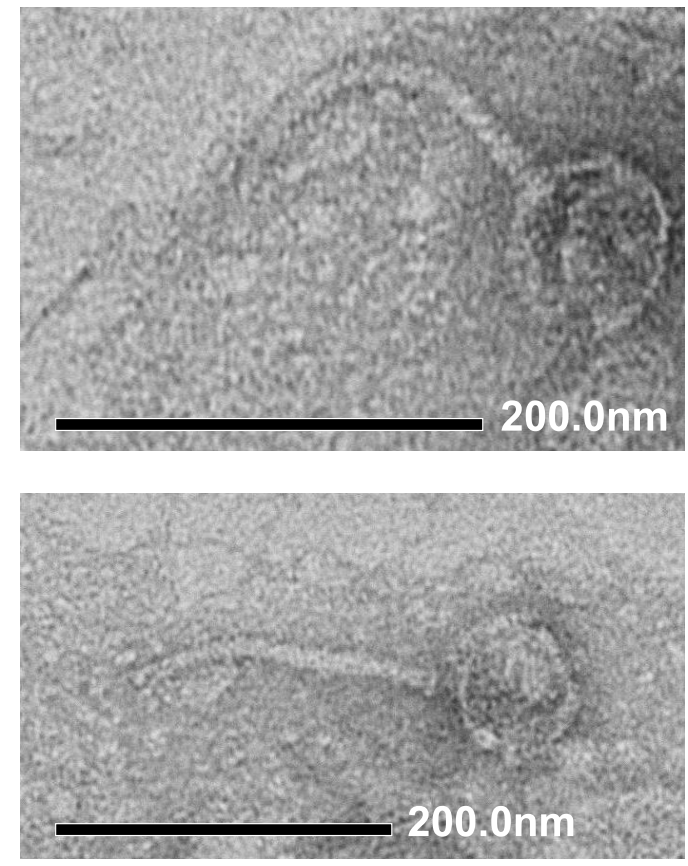

(b)

Figure 2. Morphological characteristics of vB_PmiS_PM-CJR. (a) Plaque morphology. The presence of semi-turbid haloes surrounding the plaques proper is visible after $24 \mathrm{~h}$ (top). Expansion of haloes after $48 \mathrm{~h}$ (bottom). (b) Transmission electron microscopy of phage particles. Phage particles were stained with $1 \%$ uranyl acetate and visualized at $40,000 \times($ top) and $30,000 \times$ (bottom) magnification.

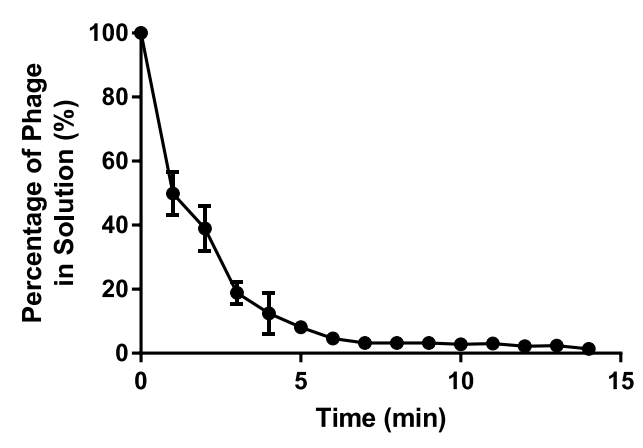

(a)

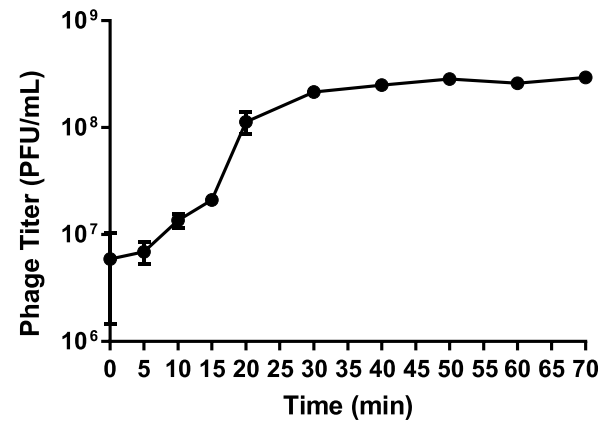

(b)

Figure 3. Growth characteristics of vB_PmiS_PM-CJR. (a) The host adsorption assay. The percentage of the phage that did not adsorb to the host cells is shown on the y axis. (b) One-step growth curve. Phage titer at different times is shown on the $\mathrm{y}$ axis, time point 0 corresponds to the moment of the first plating ( $26 \mathrm{~min}$ post-infection). Mean values $\pm \mathrm{SD}$ (standard deviation) of three independent experiments are plotted.

\subsubsection{Phage Host Range}

The host range of the phage was determined against 17 different clinical and reference isolates of $P$. mirabilis, one strain of P. vulgaris, and one strain of P. penneri. Spot tests were performed via top agar overlay technique revealing that the phage was able to infect nine of the 14 P. mirabilis strains tested and was able to infect both the P. vulgaris and the P. penneri strains (Table 1). 
Table 1. Host range determination of the purified phage vB_PmiS_PM-CJR and its recombinant tail spike protein.

\begin{tabular}{ccccc}
\hline Species & Source & Phage & Tail Spike & Reference \\
\hline P. mirabilis BB2000 & Reference strain & +++ & +++ & {$[17]$} \\
P. mirabilis ATCC 51286 & Reference strain & +++ & - & - \\
P. mirabilis ATCC 35508 & Reference strain & ++ & - & - \\
P. mirabilis HI4320 ure & Urease-negative mutant & - & - & {$[47]$} \\
P. mirabilis B2 & Clinical isolate & + & - & {$[48]$} \\
P. mirabilis B4 & Clinical isolate & ++ & - & {$[49]$} \\
P. mirabilis RB6 & Clinical isolate & - & - & {$[50]$} \\
P. mirabilis RB6A & Clinical isolate & - & - & - \\
P. mirabilis RB6B & Clinical isolate & - & - & - \\
P. mirabilis RS1 & Clinical isolate & - & - & {$[51]$} \\
P. mirabilis RS6 & Clinical isolate & - & - & {$[52]$} \\
P. mirabilis RS17 & Clinical isolate & - & - & {$[52]$} \\
P. mirabilis RS18 & Clinical isolate & - & - & {$[52]$} \\
P. mirabilis RS28 & Clinical isolate & + & - & {$[52]$} \\
P. mirabilis RS40 & Clinical isolate & ++ & - & {$[52]$} \\
P. mirabilis RS47 & Clinical isolate & ++ & - & {$[52]$} \\
P. mirabilis RS50a & Clinical isolate & + & - & {$[52]$} \\
P. penneri NCTC 12737 & Reference strain & + & - & - \\
P. vulgaris UM266 & Clinical isolate & + & - & - \\
\hline
\end{tabular}

The level of effect of phage and the tail spike on different bacterial strains was qualitatively assessed and expressed using the following convention: strong effect $(+++)$, moderate effect $(++)$, weak effect $(+)$, no detectable effect $(-)$.

\subsubsection{Thermal Stability}

The thermal stability of phage vB_PmiS_PM-CJR was assessed by exposing a $500 \mu \mathrm{L}$ sample of phage $\left(1 \times 10^{10} \mathrm{PFU} / \mathrm{mL}\right)$ to a range of temperatures from 40 to $100{ }^{\circ} \mathrm{C}$ for the duration of $1 \mathrm{~h}$, after which the titer of the phage was measured using double agar plaque assay. The data seen in Figure 4 shows that the virus is relatively thermally stable as the titer remains reduced less than $1 \log _{10}$ until $70{ }^{\circ} \mathrm{C}$, with temperatures below $60^{\circ} \mathrm{C}$ having virtually no effect on the viability of the phage. The presence of viable phage particles was still detected even after incubations at temperatures of 85 and $90^{\circ} \mathrm{C}$ for $1 \mathrm{~h}$.

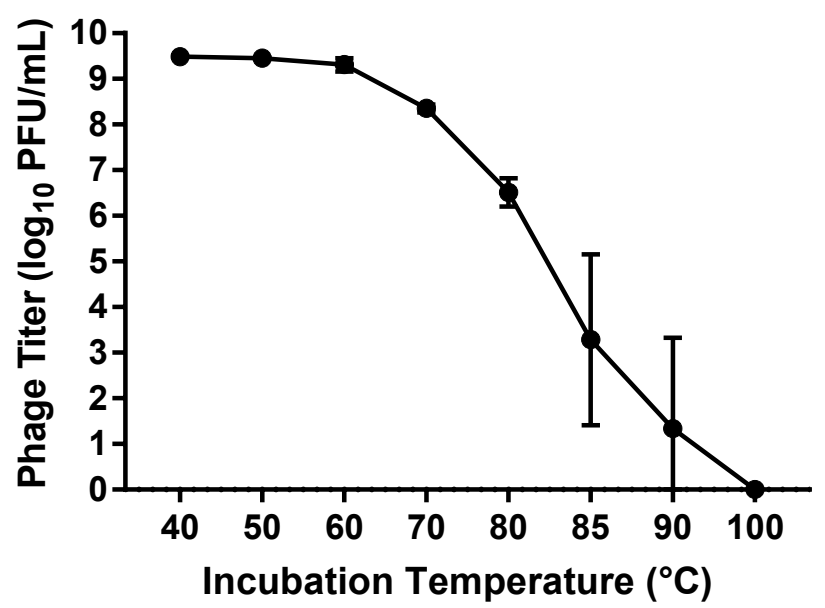

Figure 4. Thermal stability assay results. The titer $\left(\log _{10}\right.$ PFU (plaque forming units)/mL) of phage remaining after incubation at temperatures from 40 to $100{ }^{\circ} \mathrm{C}$ for $1 \mathrm{~h}$ is shown. Mean values $\pm \mathrm{SD}$ of three independent experiments are plotted.

\subsection{Genome Analysis and Phylogenetic Comparison}

\subsubsection{General Characterization of the vB_PmiS_PM-CJR Genome}

The linear dsDNA genome of the phage vB_PmiS_PM-CJR was sequenced to describe its main genomic features and determine the localization of the gene encoding polysac- 
charide depolymerase. A single contiguous sequence of 54,169 bp was assembled from $8,409,016$ reads with more than $150 \times$ coverage. An analysis of the assembled genomic sequence conducted with PhageTerm suggested that vB_PmiS_PM-CJR utilizes a headful packaging mechanism (P1 type); the DNA sequence was rearranged to align the start of the sequence with the predicted packaging site. The GC content of the phage was found to be $36.3 \%$, which is slightly lower than that of the isolation host strain Proteus mirabilis BB2000, whose GC content is $38.6 \%$ [17]. This is in line with the described tendency of intracellular parasites to have lower GC content than their hosts [53].

In terms of the genetic composition, ninety-three putative open reading frames (ORFs) were predicted in the vB_PmiS_PM-CJR genome, with 41 ORFs on the positive strand and 52 ORFs on the negative one (Figure 5). The coding percentage was estimated to be $94.4 \%$, and no tRNA genes or other non-coding RNA genes were identified. Only 47 of 93 ORFs (50.5\%) could be functionally annotated; the remaining genes were designated as encoding hypothetical proteins. Among the annotated genes, genes of DNA processing and packaging machinery, structural and lytic proteins, and the genes encoding various components of replication, recombination, and repair molecular mechanisms were identified, all forming distinct functional modules. No genes coding for proteins with significant similarity to those associated with temperate lifestyle (e.g., integrases, repressor proteins) were identified, suggesting that the phage vB_PmiS_PM-CJR is lytic. Similarly, no genes encoding auxiliary metabolic genes, virulence factors, toxins, or antibiotic resistance genes were found among the annotated genes. An annotated genome sequence of the phage vB_PmiS_PM-CJR was deposited in NCBI GenBank under the accession number MZ643249.

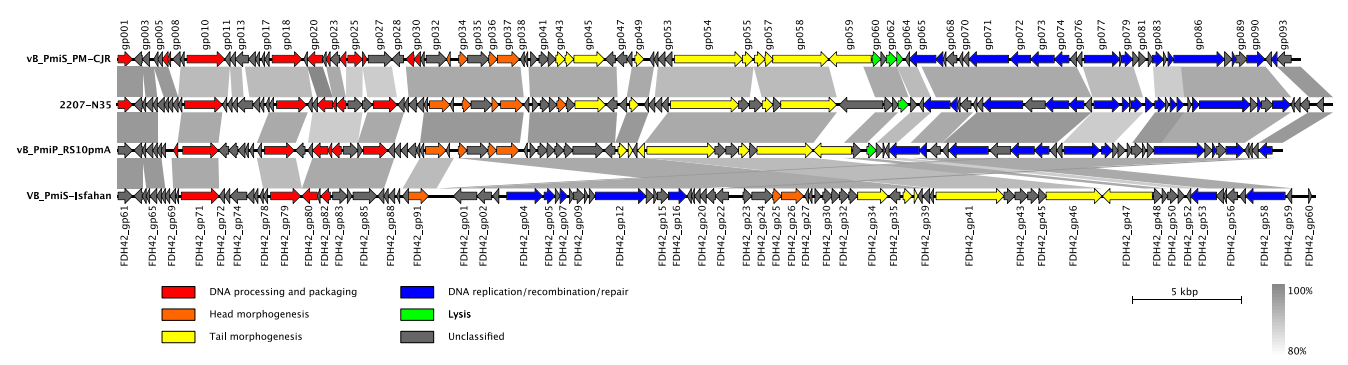

Figure 5. Genomic organization and whole-genome comparison of vB_PmiS_PM-CJR and closely related phages. Areas of substantial similarity between two genomes are shown as trapezia connecting two genome regions colored according to average nucleotide identity levels of these regions (as calculated by BLASTn). Arrows on the genome map represent identified genes and demonstrate the direction of their transcription. They are colored to reflect common functions of the encoded products. Putative genes with unidentified function are shown in grey color. Original functional annotations were used for each of the genomes.

\subsubsection{Whole Genome Comparison and Phylogenetic Analysis}

Based on the overall nucleotide identity to the vB_PmiS_PM-CJR genomic sequence, three closely related bacteriophages were identified in NCBI Genbank. These bacteriophages were annotated as Proteus phages 2207-N35 (MN840487.1), vB_PmiP_RS10pmA (MG575420.1), and VB_PmiS-Isfahan (NC_041925.1), all being classified as members of the Gorganvirus genus in the Siphoviridae family. The results of comparison of genome structure and organization of all four closely related phages are presented in Figure 5. Although all genomes are quite similar in terms of length, overall sequence identity, and gene number, several differences can be seen in the illustration. The most noticeable is a large inversion present in the genome of VB_PmiS-Isfahan compared to the other three phages. A number of regions of low sequence identity are also present, the majority of which are concentrated in genes encoding proteins with unknown function, mainly co-localized with early genes responsible for hijacking of the transcriptional and translational machinery of the host cell. 
Another noticeable difference is present in the $3^{\prime}$ end of the tail spike protein (gp059 in vB_PmiS_PM-CJR) responsible for host recognition and infection.

A comparison conducted using VIRIDIC allowed us to tentatively place vB_PmiS_PMCJR in the same Gorganvirus genus as three other analyzed phages (all phages had intergenomic similarity in the range $82-85 \%$ ). To further establish the phylogenetic relationship of vB_PmiS_PM-CJR with other tailed phages, two highly conserved genes, major capsid protein (MCP; gp037) and the large terminase subunit (TerL; gp010), were used to generate phylogenetic trees (Figure S1). The comparison of the resulting trees suggests that vB_PmiS_PM-CJR is most closely related to three other Gorganviruses of Proteus and to Salmonella phages 9NA, SP069 (Nonanviruses) and Sashavirus vB_SenS_Sasha. These results are similar to those previously reported for VB-PmiS-Isfahan [54].

\subsubsection{Putative Polysaccharide Depolymerase of vB_PmiS_PM-CJR}

Phage structural proteins, such as tail fibers and tail spikes, often contain domains with polysaccharide depolymerase activities. The tail spike protein (gp059) was analyzed with NCBI CDD and InterProScanA, revealing the presence of a pectin lyase-like fold (InterProScan IPR011050; residues 173-434) and some similarity to pectate_lyase_3 domain (pfam12708; residues 170-221), whereas the N-terminal region (residues 1-128) had a high degree of conservation between vB_PmiS_PM-CJR and three other Gorganviruses. A comparison of amino acid sequences of tail spikes of all four phages can be found in Figure S2a.

Protein modeling of the tail spike was performed in I-TASSER (Figure S2b). The resulting model had a C-score of -1.06 and the estimated TM-score was $0.58 \pm 0.14$, signifying acceptable modeling confidence and indicating the correct topology of the generated model. The tail spike protein model was used for a subsequent structural comparison to the PDB (v 2019-08-04) with mTM-align, which revealed high similarity of the model to tail spike proteins 4 (TSP4DN; ORF213; TM-score > 0.91) and 2 (TSP2DN; ORF211; TM-score > 0.59) of the bacteriophage CBA120 [55].

\subsection{Phage Depolymerase Characterization}

3.3.1. Tail Spike Protein Expression, Purification and Confirmation of Enzymatic Activity

Genomic analysis of vB_PmiS_PM-CJR suggested the presence of a putative pectin lyase in its tail spike protein. The gp059 gene construct was synthesized by Genscript and the resultant plasmid was expressed in E. coli. A band of the expected size $(72 \mathrm{kDa})$ was visible on an SDS-PAGE (Figure 6a). The recombinant protein was purified for subsequent experiments using the ÄKTA Prime Plus chromatography system (Figure S3).

A dilution series of the purified tail spike was prepared and tested by a spot test to assess its enzymatic activity, using vB_PmiS_PM-CJR for comparison (Figure 6b). The test confirmed that the protein retained its depolymerase activity in its isolated form.

\subsubsection{Antibiofilm MBEC Adherence Assay}

We used an MBEC assay to assess the antibiofilm properties of the recombinant tail spike protein. An overnight culture of $P$. mirabilis BB2000 diluted to $\mathrm{OD}_{600} 0.1$ was added to LB broth supplemented with the tail spike protein to a final concentration of $100 \mu \mathrm{g} / \mathrm{mL}$. The adherence of the bacteria to MBEC pegs was assessed after a $4 \mathrm{~h}$ timepoint. Colony counts of the sonicated pegs revealed that the presence of the tail spike protein was able to account for a 10-fold reduction in bacteria that had adhered to the MBEC pegs. Statistical analysis revealed the difference in colony counts between the treated group and the untreated group was significant with $p<0.0001$ (Figure 7a). The reduction observed may indicate that the tail spike protein holds antimicrobial potential against $P$. mirabilis and their associated infections. 


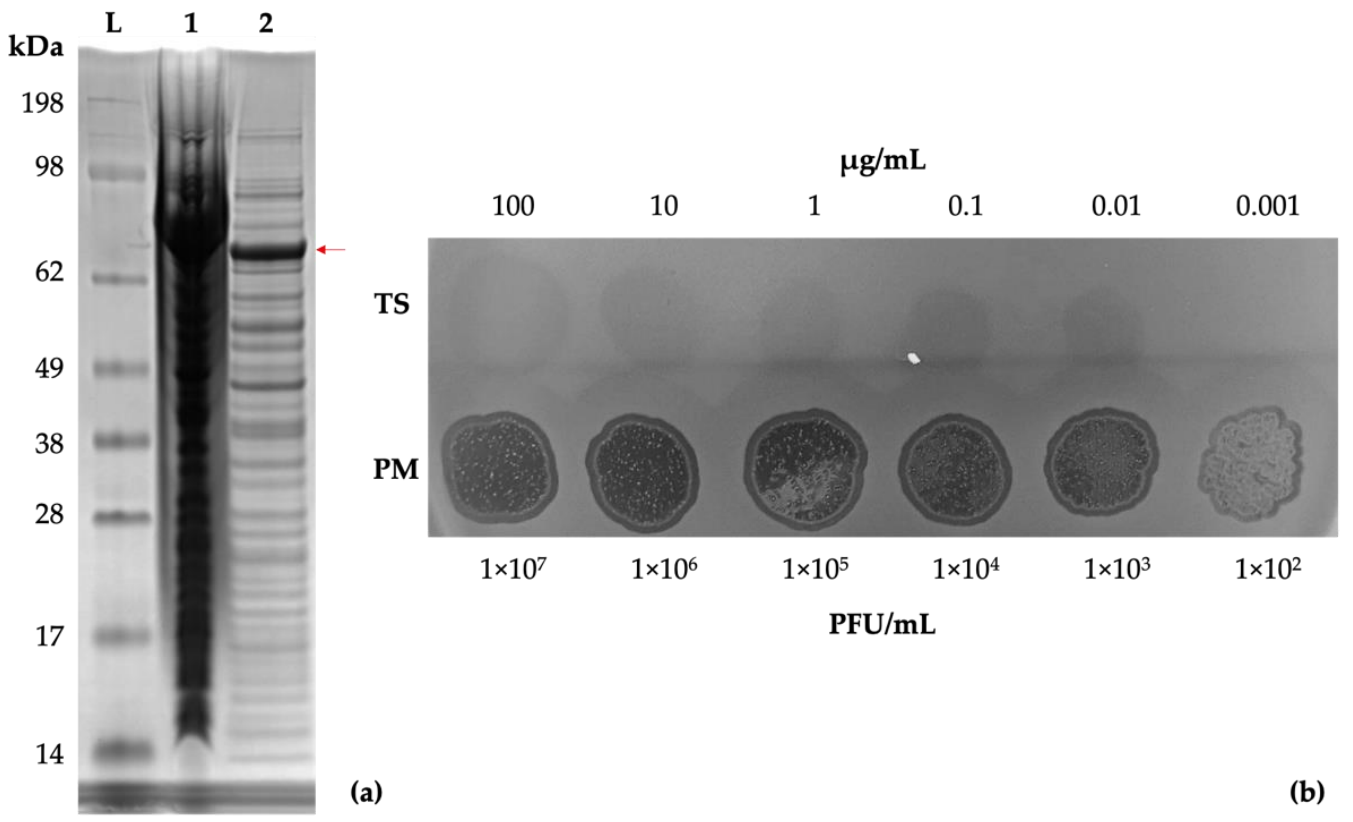

Figure 6. Tail spike expression and confirmation of activity. (a) SDS-PAGE gel of E. coli KRX cells expressing the recombinant tail spike protein. Lanes: SeeBlue Plus2 reference ladder (L), total protein (1), soluble protein fraction (2). A band of approximately $72 \mathrm{kDa}$, corresponding to a monomer of the tail spike protein, is visible (indicated with a red arrow). (b) Spot testing $(10 \mu \mathrm{L})$ of the purified tail spike protein and phage suspension on a lawn of P. mirabilis BB2000.

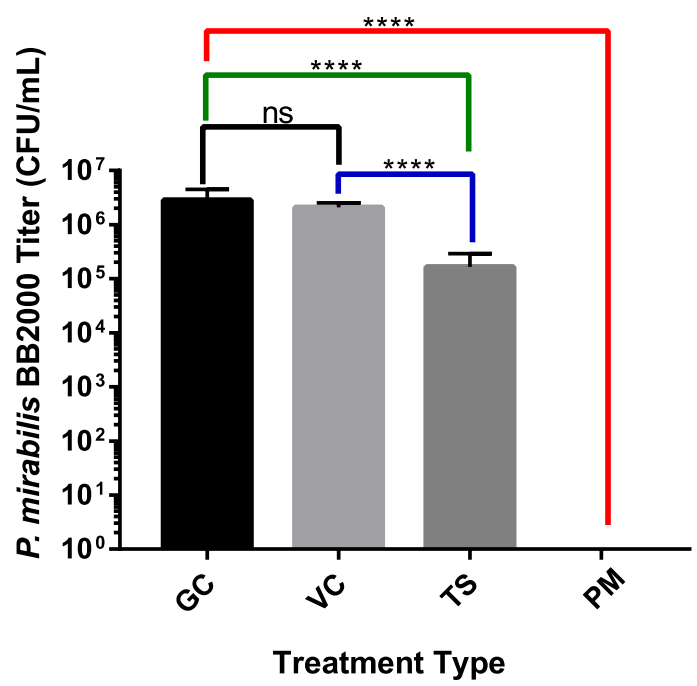

(a)

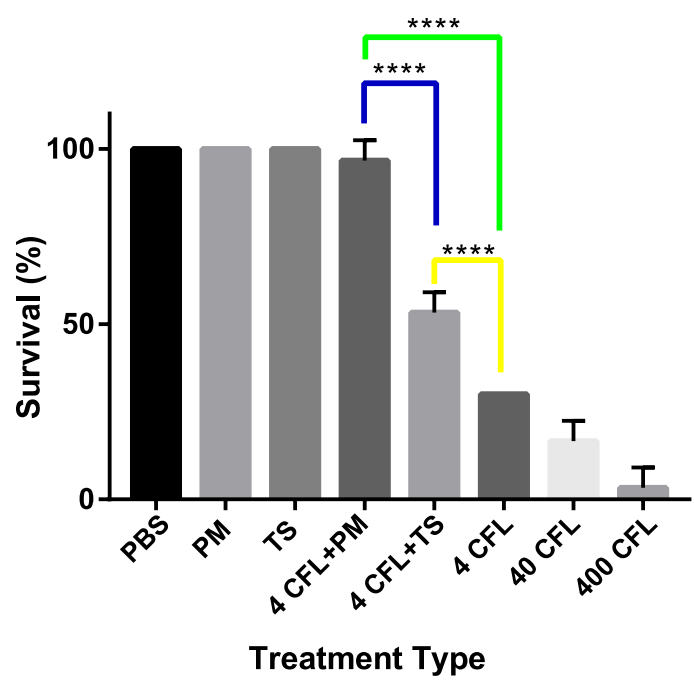

(b)

Figure 7. Analysis of antimicrobial activity of the phage vB_PmiS_PM-CJR and its tail spike. (a) MBEC (minimum biofilm eradication concentration) adherence assay. Treatments: GC—growth control, VC—vehicle control (50 $\mathrm{mM} \mathrm{Tris-HCl} \mathrm{pH} 8.0$ in LBB), TS—-tail spike dialyzed into vehicle, PM-phage vB_PmiS_PM-CJR in $1 \times$ PBS. (b) Galleria mellonella infection model. The number of surviving larvae $48 \mathrm{~h}$ post-treatment are shown. Treatments (all in $1 \times$ PBS): PBS—buffer only, PM-phage only, TS-tail spike only; 4, 40, and 400 CFL_Proteus mirabilis injections of 4, 40, and 400 CFU (colony forming units)/larva. Modifiers +PM and +TS are used to indicate administration of either $2 \times 10^{5}$ vB_PmiS_PM-CJR phage particles or $2 \mu \mathrm{g}$ of the purified tail spike protein per larva, respectively. Both experiments were conducted in triplicate, mean values $\pm \mathrm{SD}$ are reported; ns—not significant, ${ }^{* * *} \_p<0.0001$ (one-way ANOVA with Tukey's post-hoc test).

\subsubsection{Galleria mellonella Survivability Study}

To further assess the antimicrobial activity of the tail spike protein, a G. mellonella survivability study was designed in which the recombinant tail spike was injected $(100 \mu \mathrm{g} / \mathrm{mL})$ 
immediately after injection of different titers of $P$. mirabilis. The whole phage vB_PmiS_PMCJR was also used in the study to assess its antimicrobial potential. Injection of the phage $\left(1 \times 10^{7} \mathrm{PFU} / \mathrm{mL}\right)$ at both bacterial concentrations significantly increased the survivability of the larvae (Figure $7 \mathrm{~b}$ ). The phage was also shown to be non-toxic to the larvae at the titers up to $1 \times 10^{11} \mathrm{PFU} / \mathrm{mL}$ (data not shown). Injection of the tail spike protein was also found to be effective at improving G. mellonella survivability after $48 \mathrm{~h}$ when compared to the untreated controls. The whole phage allowed for $40 \%$ increased survival when compared to the tail spike treatment. Application of the tail spike facilitated an increased $20 \%$ survival when compared to the untreated control group.

\section{Discussion}

Biofilm formation is a characteristic property of many microorganisms causing medical device-associated infectious diseases. Among such infections, CAUTIs constitute a significant proportion and Proteus mirabilis is responsible for a substantial number of them, especially in patients with long-term catheterization and in case of complicated UTIs $[1,56]$. Due to its unique ability to form crystalline biofilms, established P. mirabilis infections are difficult to treat with conventional antibiotics [56]. In addition, the prevalence of antibiotic-resistant Proteus spp. strains is increasing, necessitating a more intensive search for alternative approaches [57]. The use of therapeutic bacteriophages and their enzymes for biofilm control is a promising research direction—a number of phage cocktails have been tested in clinical trials, including a recently finished one, in which bacteriophage therapy was found to be non-inferior to the standard-of-care antibiotic treatment of UTIs [58-61]. The research into the application of bacteriophages against Proteus has attracted a certain amount of attention (e.g., [45,62]), with a recent study reporting encouraging results of the use of phage-functionalized hydrogels for the prevention of catheter blockage [60].

In contrast to whole-phage preparations, isolated natural and genetically engineered enzymes of Proteus phages (endolysins, polysaccharide depolymerases) have not been intensively investigated as antibacterial agents, especially in comparison with other Gramnegative pathogens [63-65]. In a recent work, Alves et al. reported that the majority of Proteus phages they studied produced clear plaques surrounded by haloes, which is a wellknown characteristic of phage depolymerase activity; despite that, the authors were unable to identify the ORFs encoding potential depolymerases in the genomes of the bacteriophages they sequenced [66]. As it was shown previously that other phages effective in controlling biofilm formation by Proteus mirabilis produce expanding haloes [67], we attempted to isolate the factor responsible for this activity from a novel halo-forming bacteriophage whose microbiological and genetic characteristics we describe in the present study.

The genome sequencing and comparative bioinformatics analysis revealed that the isolated bacteriophage is a new representative of a recently established genus of Gorganviruses, Siphoviridae, whose first member was described in the publication by Yazdi et al. [54]. The bioinformatics analysis of our phage vB_PmiS_PM-CJR was in agreement with the microscopy results, which confirmed its siphoviral morphology. Although the genome sequences of vB_PmiS_PM-CJR and three other Gorganviruses have substantial nucleotide identity, they together are relatively distant from other bacteriophage groups. Further analyses based on reconstruction of phylogenetic trees using MCP and TerL proteins have also demonstrated that vB_PmiS_PM-CJR is closely related to Gorganviruses and (to a less extent) to a number of other Siphoviridae, most notably genera Noravirus and Sashavirus of Salmonella. The phylogenetic relationships with more distantly related phages are less obvious from the trees, as their topologies and phages constituting them differ significantly.

The majority of phage polysaccharide depolymerases are found within or in close proximity to genes of tail fibers and tail spikes, and thus can be considered structural proteins [68]. Although polysaccharide depolymerases are structurally similar, central regions of the genes encoding them are highly variable and can significantly differ even between closely related phage species [69]. As a comparative genomic analysis showed the absence of sequence conservation in the gene of a tail spike protein of vB_PmiS_PM-CJR 
and the presence of a putative pectate lyase domain was predicted by InterProScan and NCBI CDD, we decided to investigate the tail spike in more detail to verify the presence of polysaccharide depolymerase in it.

The purified tail spike was tested using a lawn spot test alongside the vB_PmiS_PMCJR. The formation of semi-turbid spots similar in appearance to haloes surrounding phage plaques confirmed the presence of polymer-degrading enzymatic activity. To further assess the activity of the depolymerase and its potential applicability as an antibiofilm agent, the enzyme was tested in an MBEC assay. The enzyme interfered with the attachment of Proteus to plastic pegs of the MBEC device, reducing the number of adsorbed bacteria by $90 \%$, indicating the protein may hold potential for catheter treatment and prevention of P. mirabilis colonization of catheters. Finally, we showed that an injection of the tail spike protein reduces mortality of G. mellonella from P. mirabilis, with five of 10 larvae surviving after $48 \mathrm{~h}$ post-infection with $4 \mathrm{CFU} /$ larva, compared to three of 10 in the control group on average. Due to the fact that the larval immune system of $G$. mellonella has a number of similarities to the innate immune response of humans and other mammals, it is widely used as a model to study host-pathogen interactions and immune responses [70]. This model has previously been applied to assess the efficiency of different antimicrobial agents, including bacteriophages and their enzymes [71,72]. As Proteus mirabilis is highly lethal to G. mellonella larvae (previously reported $\mathrm{LD}_{50}$ are in the range of 10-100 CFU/larva, which is in agreement with our findings) [73,74], our results demonstrate that the depolymerase has a noticeable antivirulence effect.

Polysaccharide elements appear to play a major role in the genesis of Proteus biofilms, forming a foundation layer [75]. Although we showed that the tail spike has an effect on Proteus cells, its exact target is currently unknown. Pectin/pectate lyases (EC 4.2.2.10 or 4.2.2.2) are among the most common depolymerases produced by phages [68] and are known to degrade negatively charged non-methylated, low-esterified substrates, by acting on the $\alpha-1,4$ bonds between galacturonosyl residues [76]. The presence of a pectate lyase domain implies that the enzyme is capable of degrading polygalacturonic acid, a major component of bacterial polysaccharides. Galacturonic acid and its derivatives are frequently present in O-antigens of Proteus lipopolysaccharides (LPS), which may be the target of the tail spike activity [77]. Interestingly, structural modeling of the tail spike suggested that it is structurally similar to the hydrolysases TSP4 (PDB: 5w6h) encoded by ORF213 E. coli phage CBA120 and, to a lesser extent, to TSP2 from the same phage [55,78]. Nevertheless, although it may indicate that the tail spike of vB_PmiS_PM-CJR has similar activity, the low general accuracy of computational protein structure prediction of phage proteins and high level of structural conservation among phage depolymerases mean that the depolymerase target cannot be established reliably with this approach. Alternatively, the tail spike might be active against a capsular polysaccharide (CPS) produced by Proteus cells. A number of publications report the presence of a capsule and its involvement in the formation of crystalline biofilms by Proteus mirabilis [4,79-84], although not all strains of Proteus can synthesize it [85]; no capsule was detected following multiple capsule staining attempts of P. mirabilis BB2000 (data not shown). In Proteus strains that produce CPS, its structure appears to be identical to O-specific chains of their LPS [79,85,86]. Finally, a possibility of existing of another polymeric target (e.g., EPS of the glycocalyx) for the tail spike cannot be excluded.

Arguably, one of the main limitations to implementing phage depolymerases as antivirulence agents, whether alone or in combination with other antibacterials, is their narrow spectrum of activity. Although the host range of phage vB_PmiS_PM-CJR included a number of strains of $P$. mirabilis, in addition to P. vulgaris and P. penneri strains, the recombinant tail spike protein was limited to just its original vB_PmiS_PM-CJR isolation strain P. mirabilis BB2000 (Table 1), indicating that the tail spike protein is very specific to this particular host or that its binding to the components of the polymeric matrix was not followed by their enzymatic degradation. The presence of other receptor-binding proteins additional to gp059 in vB_PmiS_PM-CJR may also explain the wider host range 
of the phage compared to the depolymerase. Although the narrow activity spectrum of phages is considered beneficial for clinical applications as it limits the effect of the phage on non-pathogenic constituents of the microbiota, protein engineering of the tail spike can be employed to expand its host range [87-89].

Phage polysaccharide depolymerases are promising antibacterial agents and tools for studying bacterial polysaccharides and phage-bacteria co-evolution. We demonstrated that the isolated tail spike has potential to reduce colonization of polymer surfaces by interfering with the formation of Proteus biofilms and improves survival of infected Galleria mellonella. We are planning to continue our investigation to better describe the isolated depolymerase by identifying the target polysaccharide and conducting its additional biochemical characterization. It should be noted that a phage depolymerase with promising antivirulence properties was recently identified in a podovirus infecting Providencia stuartii, an emerging nosocomial pathogen [90]. As Proteus, Providencia, and Morganella are closely related, it would be interesting to further investigate the diversity and the spectrum of activity of depolymerases from phages of that group of bacteria and attempt to identify ones with a broader range of targets.

\section{Conclusions}

In this study we isolated a new Proteus bacteriophage and determined that its recombinant tail spike protein has polysaccharide depolymerase activity. To the best of our knowledge, this is the first polysaccharide depolymerase from a Proteus bacteriophage described in the literature. We experimentally demonstrated its antibacterial properties and believe that our results may contribute to development of novel approaches of treatment and prevention of CAUTIs caused by Proteus.

Supplementary Materials: The following are available online at https:/ /www.mdpi.com/article/10 .3390/microorganisms9102172/s1. Figure S1: Phylogenetic trees based on amino acid sequences of terminase large subunit and major capsid protein of phage vB_PmiS_PM-CJR and related bacteriophages. Figure S2: Multiple sequence alignment of the tail spike protein sequences of vB_PmiS_PMCJR and related Gorganviruses and a structural model of the vB_PmiS_PM-CJR tail spike generated with I-TASSER. Figure S3: Purified protein RP-HPLC analysis results.

Author Contributions: Conceptualization, T.S. and C.J.R.; methodology, C.J.R., T.S., S.A.K. and S.C.O.; data curation, C.J.R. and T.S.; formal analysis, C.J.R. and T.S.; investigation, C.J.R., S.A.K., S.C.O., E.M.M., J.C.B.G., Z.H.C. and T.S.; resources, E.M.M., J.C.B.G. and Z.H.C.; software, C.J.R. and T.S.; validation, C.J.R.; writing—original draft preparation, C.J.R. and T.S.; writing-review and editing, C.J.R., T.S., S.A.K. and B.F.G.; visualization, C.J.R., S.C.O. and T.S.; supervision, T.S., B.F.G.; project administration, T.S.; funding acquisition, T.S. All authors have read and agreed to the published version of the manuscript.

Funding: This work was supported by a Northern Ireland Department for the Economy (DfE) Studentship to C.J.R., Wellcome Trust Biomedical Vacation Scholarship to J.C.B.G. (ref. no.: 216936/Z/19/Z) and Cystic Fibrosis Trust and British Lung Foundation summer studentship award to Z.H.C. (CFT Project No: SS19/08).

Data Availability Statement: All data produced in this study is available in the main text of the publication or in the Supplementary Materials.

Acknowledgments: We are grateful to Sreekanth Pentlavalli for his help with the HPLC analysis of the purified tail spike protein. The authors would also like to thank Ronan McDaid for his assistance with the thermal stability assay.

Conflicts of Interest: The authors declare no conflict of interest. The funders had no role in the design of the study; in the collection, analyses, or interpretation of data; in the writing of the manuscript, or in the decision to publish the results. 


\section{References}

1. Jacobsen, S.M.; Stickler, D.J.; Mobley, H.L.T.; Shirtliff, M.E. Complicated Catheter-Associated Urinary Tract Infections Due to Escherichia coli and Proteus mirabilis. Clin. Microbiol. Rev. 2008, 21, 26-59. [CrossRef] [PubMed]

2. Sriwanthana, B.; Mobley, H. Proteus mirabilis urease: Histidine 320 of UreC is essential for urea hydrolysis and nickel ion binding within the native enzyme. Infect. Immun. 1993, 61, 2570-2577. [CrossRef] [PubMed]

3. Milo, S.; Heylen, R.A.; Glancy, J.; Williams, G.T.; Patenall, B.L.; Hathaway, H.J.; Thet, N.T.; Allinson, S.L.; Laabei, M.; Jenkins, A.T.A. A small-molecular inhibitor against Proteus mirabilis urease to treat catheter-associated urinary tract infections. Sci. Rep. 2021, 11, 1-15. [CrossRef] [PubMed]

4. Wasfi, R.; Hamed, S.; Amer, M.A.; Fahmy, L.I. Proteus mirabilis Biofilm: Development and Therapeutic Strategies. Front. Cell. Infect. Microbiol. 2020, 10, 414. [CrossRef] [PubMed]

5. Myelnikov, D. An Alternative Cure: The Adoption and Survival of Bacteriophage Therapy in the USSR, $1922-1955$. J. Hist. Med. Allied Sci. 2018, 73, 385-411. [CrossRef] [PubMed]

6. Hatfull, G.F.; Dedrick, R.M.; Schooley, R.T. Phage Therapy for Antibiotic-Resistant Bacterial Infections. Annu. Rev. Med. 2021, 73, 1-15. [CrossRef]

7. Altamirano, F.L.G.; Barr, J.J. Phage Therapy in the Postantibiotic Era. Clin. Microbiol. Rev. 2019, 32, 1-25. [CrossRef]

8. Weitz, J.S.; Hartman, H.; Levin, S. Coevolutionary arms races between bacteria and bacteriophage. Proc. Natl. Acad. Sci. USA 2005, 102, 9535-9540. [CrossRef]

9. Lemieux, J.; Hatfull, G. Set Phages to Kill: An Interview with Graham Hatfull, PhD. PHAGE 2020, 1, 4-9. [CrossRef]

10. Oechslin, F. Resistance Development to Bacteriophages Occurring during Bacteriophage Therapy. Viruses 2018, 10, 351. [CrossRef]

11. Gondil, V.S.; Chhibber, S. Bacteriophage and Endolysin Encapsulation Systems: A Promising Strategy to Improve Therapeutic Outcomes. Front. Pharmacol. 2021, 12, 675440. [CrossRef] [PubMed]

12. Housby, J.N.; Mann, N.H. Phage therapy. Drug Discov. Today 2009, 14, 536-540. [CrossRef] [PubMed]

13. Lin, H.; Paff, M.L.; Molineux, I.J.; Bull, J.J. Antibiotic Therapy Using Phage Depolymerases: Robustness Across a Range of Conditions. Viruses 2018, 10, 622. [CrossRef] [PubMed]

14. Wu, Y.; Wang, R.; Xu, M.; Liu, Y.; Zhu, X.; Qiu, J.; Liu, Q.; He, P.; Li, Q. A Novel Polysaccharide Depolymerase Encoded by the Phage SH-KP152226 Confers Specific Activity Against Multidrug-Resistant Klebsiella pneumoniae via Biofilm Degradation. Front. Microbiol. 2019, 10, 2768. [CrossRef]

15. Guo, Z.; Huang, J.; Yan, G.; Lei, L.; Wang, S.; Yu, L.; Zhou, L.; Gao, A.; Feng, X.; Han, W.; et al. Identification and Characterization of Dpo42, a Novel Depolymerase Derived from the Escherichia coli Phage vB_EcoM_ECOO78. Front. Microbiol. 2017, 8, 1460. [CrossRef]

16. Wang, C.; Li, P.; Zhu, Y.; Huang, Y.; Gao, M.; Yuan, X.; Niu, W.; Liu, H.; Fan, H.; Qin, Y.; et al. Identification of a Novel Acinetobacter baumannii Phage-Derived Depolymerase and Its Therapeutic Application in Mice. Front. Microbiol. 2020, 11, 1407. [CrossRef]

17. Sullivan, N.L.; Septer, A.; Fields, A.T.; Wenren, L.M.; Gibbs, K.A. The Complete Genome Sequence of Proteus mirabilis Strain BB2000 Reveals Differences from the P. mirabilis Reference Strain. Genome Announc. 2013, 1, 643-644. [CrossRef]

18. Clokie, M.R.J.; Kropinski, A.M. Bacteriophages: Methods and Protocols Volume 2: Molecular and Applied Aspects; Humana Press: Totowa, NJ, USA, 2009; pp. XXII, 373.

19. John, S.G.; Mendez, C.B.; Deng, L.; Poulos, B.; Kauffman, K.; Kern, S.; Brum, J.; Polz, M.F.; Boyle, E.A.; Sullivan, M.B. A simple and efficient method for concentration of ocean viruses by chemical flocculation. Environ. Microbiol. Rep. 2010, 3, 195-202. [CrossRef]

20. Necel, A.; Bloch, S.; Nejman-Faleńczyk, B.; Grabski, M.; Topka, G.; Dydecka, A.; Kosznik-Kwaśnicka, K.; Grabowski, L.; JurczakKurek, A.; Wołkowicz, T.; et al. Characterization of a bacteriophage, vB_Eco4M-7, that effectively infects many Escherichia coli O157 strains. Sci. Rep. 2020, 10, 3743. [CrossRef]

21. Quiberoni, A.; Stiefel, J.; Reinheimer, J. Characterization of phage receptors in Streptococcus thermophilus using purified cell walls obtained by a simple protocol. J. Appl. Microbiol. 2000, 89, 1059-1065. [CrossRef]

22. Joshi, N.A.; Fass, J.N. Sickle: A Sliding-Window, Adaptive, Quality-Based Trimming Tool for FastQ Files (Version 1.33) [Software] 2011. Available online: https:/ / github.com/najoshi/sickle (accessed on 17 September 2020).

23. Wick, R.R.; Judd, L.M.; Gorrie, C.L.; Holt, K.E. Unicycler: Resolving bacterial genome assemblies from short and long sequencing reads. PLoS Comput. Biol. 2017, 13, e1005595. [CrossRef]

24. Garneau, J.R.; Depardieu, F.; Fortier, L.-C.; Bikard, D.; Monot, M. PhageTerm: A tool for fast and accurate determination of phage termini and packaging mechanism using next-generation sequencing data. Sci. Rep. 2017, 7, 1-10. [CrossRef]

25. Hyatt, D.; Chen, G.-L.; Locascio, P.F.; Land, M.L.; Larimer, F.W.; Hauser, L.J. Prodigal: Prokaryotic gene recognition and translation initiation site identification. BMC Bioinform. 2010, 11, 119. [CrossRef]

26. Carver, T.; Harris, S.R.; Berriman, M.; Parkhill, J.; McQuillan, J.A. Artemis: An integrated platform for visualization and analysis of high-throughput sequence-based experimental data. Bioinformatics 2012, 28, 464-469. [CrossRef]

27. Zhou, C.L.E.; Malfatti, S.; Kimbrel, J.; Philipson, C.; McNair, K.; Hamilton, T.; Edwards, R.; Souza, B. multiPhATE: Bioinformatics pipeline for functional annotation of phage isolates. Bioinformatics 2019, 35, 4402-4404. [CrossRef]

28. Altschul, S.F.; Gish, W.; Miller, W.; Myers, E.W.; Lipman, D.J. Basic local alignment search tool. J. Mol. Biol. 1990, 215, 403-410. [CrossRef]

29. Söding, J.; Biegert, A.; Lupas, A.N. The HHpred interactive server for protein homology detection and structure prediction. Nucleic Acids Res. 2005, 33, W244-W248. [CrossRef] [PubMed] 
30. Cantu, V.A.; Salamon, P.; Seguritan, V.; Redfield, J.; Salamon, D.; Edwards, R.A.; Segall, A.M. PhANNs, a fast and accurate tool and web server to classify phage structural proteins. PLoS Comput. Biol. 2020, 16, e1007845. [CrossRef]

31. Finn, R.D.; Clements, J.; Eddy, S.R. HMMER web server: Interactive sequence similarity searching. Nucleic Acids Res. 2011, 39 (Suppl. 2), W29-W37. [CrossRef] [PubMed]

32. Zhang, Y. I-TASSER server for protein 3D structure prediction. BMC Bioinform. 2008, 9, 40. [CrossRef] [PubMed]

33. Marchler-Bauer, A.; Derbyshire, M.K.; Gonzales, N.R.; Lu, S.; Chitsaz, F.; Geer, L.Y.; Geer, R.C.; He, J.; Gwadz, M.; Hurwitz, D.I.; et al. CDD: NCBI's conserved domain database. Nucleic Acids Res. 2015, 43, D222-D226. [CrossRef]

34. Jones, P.; Binns, D.; Chang, H.Y.; Fraser, M.; Li, W.; McAnulla, C.; McWilliam, H.; Maslen, J.; Mitchell, A.; Nuka, G.; et al. InterProScan 5: Genome-scale protein function classification. Bioinformatics 2014, 30, 1236-1240. [CrossRef]

35. Pettersen, E.F.; Goddard, T.D.; Huang, C.C.; Meng, E.C.; Couch, G.S.; Croll, T.I.; Morris, J.H.; Ferrin, T.E. UCSF ChimeraX: Structure visualization for researchers, educators, and developers. Protein Sci. 2021, 30, 70-82. [CrossRef]

36. Dong, R.; Pan, S.; Peng, Z.; Zhang, Y.; Yang, J. mTM-align: A server for fast protein structure database search and multiple protein structure alignment. Nucleic Acids Res. 2018, 46, W380-W386. [CrossRef]

37. Sullivan, M.J.; Petty, N.; Beatson, S.A. Easyfig: A genome comparison visualizer. Bioinformatics 2011, 27, 1009-1010. [CrossRef]

38. Moraru, C.; Varsani, A.; Kropinski, A. VIRIDIC-A Novel Tool to Calculate the Intergenomic Similarities of Prokaryote-Infecting Viruses. Viruses 2020, 12, 1268. [CrossRef]

39. Katoh, K.; Standley, D.M. MAFFT Multiple Sequence Alignment Software Version 7: Improvements in Performance and Usability. Mol. Biol. Evol. 2013, 30, 772-780. [CrossRef] [PubMed]

40. Capella-Gutierrez, S.; Silla-Martinez, J.M.; Gabaldon, T. trimAl: A tool for automated alignment trimming in large-scale phylogenetic analyses. Bioinformatics 2009, 25, 1972-1973. [CrossRef]

41. Minh, B.Q.; Schmidt, H.A.; Chernomor, O.; Schrempf, D.; Woodhams, M.D.; von Haeseler, A.; Lanfear, R. IQ-TREE 2: New Models and Efficient Methods for Phylogenetic Inference in the Genomic Era. Mol. Biol. Evol. 2020, 37, 1530-1534. [CrossRef] [PubMed]

42. Rambaut, A. FigTree: A Graphical Viewer of Phylogenetic Trees and a Figure Drawing Tool (v1.4.4) [Software]. 2009. Available online: http:/ / tree.bio.ed.ac.uk/software/figtree/ (accessed on 7 September 2021).

43. Adriaenssens, E.; Brister, J.R. How to Name and Classify Your Phage: An Informal Guide. Viruses 2017, 9, 70. [CrossRef] [PubMed]

44. Corban, J.E.; Ramsey, J. Characterization and complete genome sequence of Privateer, a highly prolate Proteus mirabilis podophage. PeerJ 2021, 9, e10645. [CrossRef] [PubMed]

45. Melo, L.D.; Veiga, P.; Cerca, N.; Kropinski, A.M.; Almeida, C.; Azeredo, J.; Sillankorva, S. Development of a Phage Cocktail to Control Proteus mirabilis Catheter-associated Urinary Tract Infections. Front. Microbiol. 2016, 7, 1024. [CrossRef] [PubMed]

46. Yazdi, M.; Bouzari, M.; Ghaemi, E.A. Isolation and Characterization of a Lytic Bacteriophage (vB_PmiS-TH) and Its Application in Combination with Ampicillin against Planktonic and Biofilm Forms of Proteus mirabilis Isolated from Urinary Tract Infection. Microb. Physiol. 2018, 28, 37-46. [CrossRef] [PubMed]

47. Jones, B.D.; Lockatell, C.V.; Johnson, D.E.; Warren, J.W.; Mobley, H. Construction of a urease-negative mutant of Proteus mirabilis: Analysis of virulence in a mouse model of ascending urinary tract infection. Infect. Immun. 1990, 58, 1120-1123. [CrossRef] [PubMed]

48. Stickler, D.; Lear, J.; Morris, N.; MacLeod, S.; Downer, A.; Cadd, D.; Feast, W. Observations on the adherence of Proteus mirabilis onto polymer surfaces. J. Appl. Microbiol. 2006, 100, 1028-1033. [CrossRef] [PubMed]

49. Jones, B.V.; Mahenthiralingam, E.; Sabbuba, N.A.; Stickler, D.J. Role of swarming in the formation of crystalline Proteus mirabilis biofilms on urinary catheters. J. Med. Microbiol. 2005, 54, 807-813. [CrossRef]

50. Broomfield, R.J.; Morgan, S.D.; Khan, A.; Stickler, D.J. Crystalline bacterial biofilm formation on urinary catheters by ureaseproducing urinary tract pathogens: A simple method of control. J. Med. Microbiol. 2009, 58, 1367-1375. [CrossRef] [PubMed]

51. Milo, S.; Thet, N.T.; Liu, D.; Nzakizwanayo, J.; Jones, B.V.; Jenkins, A.T.A. An in-situ infection detection sensor coating for urinary catheters. Biosens. Bioelectron. 2016, 81, 166-172. [CrossRef] [PubMed]

52. Pelling, H.; Bock, L.J.; Nzakizwanayo, J.; Wand, M.E.; Denham, E.L.; MacFarlane, W.M.; Sutton, J.M.; Jones, B.V. Derepression of the smvA Efflux System Arises in Clinical Isolates of Proteus mirabilis and Reduces Susceptibility to Chlorhexidine and Other Biocides. Antimicrob. Agents Chemother. 2019, 63, e01535-19. [CrossRef] [PubMed]

53. Almpanis, A.; Swain, M.; Gatherer, D.; McEwan, N. Correlation between bacterial G+C content, genome size and the G+C content of associated plasmids and bacteriophages. Microb. Genom. 2018, 4, e000168. [CrossRef]

54. Yazdi, M.; Bouzari, M.; Ghaemi, E.A. Genomic analyses of a novel bacteriophage (VB_PmiS-Isfahan) within Siphoviridae family infecting Proteus mirabilis. Genomics 2019, 111, 1283-1291. [CrossRef] [PubMed]

55. Plattner, M.; Shneider, M.M.; Arbatsky, N.P.; Shashkov, A.S.; Chizhov, A.O.; Nazarov, S.; Prokhorov, N.; Taylor, N.M.I.; Buth, S.; Gambino, M.; et al. Structure and Function of the Branched Receptor-Binding Complex of Bacteriophage CBA120. J. Mol. Biol. 2019, 431, 3718-3739. [CrossRef] [PubMed]

56. Percival, S.L.; Suleman, L.; Vuotto, C.; Donelli, G. Healthcare-associated infections, medical devices and biofilms: Risk, tolerance and control. J. Med. Microbiol. 2015, 64, 323-334. [CrossRef]

57. Girlich, D.; Bonnin, R.A.; Dortet, L.; Naas, T. Genetics of Acquired Antibiotic Resistance Genes in Proteus spp. Front. Microbiol. 2020, 11, 256. [CrossRef]

58. Górski, A.; Borysowski, J.; Międzybrodzki, R. Phage Therapy: Towards a Successful Clinical Trial. Antibiotics 2020, 9, 827. [CrossRef] 
59. Gomaa, S.; Serry, F.; Abdellatif, H.; Abbas, H. Elimination of multidrug-resistant Proteus mirabilis biofilms using bacteriophages. Arch. Virol. 2019, 164, 2265-2275. [CrossRef]

60. Milo, S.; Hathaway, H.; Nzakizwanayo, J.; Alves, D.R.; Esteban, P.P.; Jones, B.V.; Jenkins, A.T.A. Prevention of encrustation and blockage of urinary catheters by Proteus mirabilis via $\mathrm{pH}$-triggered release of bacteriophage. J. Mater. Chem. B 2017, 5, 5403-5411. [CrossRef]

61. Leitner, L.; Ujmajuridze, A.; Chanishvili, N.; Goderdzishvili, M.; Chkonia, I.; Rigvava, S.; Chkhotua, A.; Changashvili, G.; McCallin, S.; Schneider, M.P.; et al. Intravesical bacteriophages for treating urinary tract infections in patients undergoing transurethral resection of the prostate: A randomised, placebo-controlled, double-blind clinical trial. Lancet Infect. Dis. 2021, 21, 427-436. [CrossRef]

62. Carson, L.; Gorman, S.P.; Gilmore, B.F. The use of lytic bacteriophages in the prevention and eradication of biofilms of Proteus mirabilis and Escherichia coli. FEMS Immunol. Med. Microbiol. 2010, 59, 447-455. [CrossRef]

63. Abdelrahman, F.; Easwaran, M.; Daramola, O.; Ragab, S.; Lynch, S.; Oduselu, T.; Khan, F.; Ayobami, A.; Adnan, F.; Torrents, E.; et al. Phage-Encoded Endolysins. Antibiotics 2021, 10, 124. [CrossRef] [PubMed]

64. Knecht, L.E.; Veljkovic, M.; Fieseler, L. Diversity and Function of Phage Encoded Depolymerases. Front. Microbiol. 2020, 10, 2949. [CrossRef]

65. Yan, J.; Mao, J.; Xie, J. Bacteriophage Polysaccharide Depolymerases and Biomedical Applications. BioDrugs 2013, 28, 265-274. [CrossRef]

66. Alves, D.R.; Nzakizwanayo, J.; Dedi, C.; Olympiou, C.; Hanin, A.; Kot, W.; Hansen, L.; Lametsch, R.; Gahan, C.G.M.; Schellenberger, P.; et al. Genomic and Ecogenomic Characterization of Proteus mirabilis Bacteriophages. Front. Microbiol. 2019, 10, 1783. [CrossRef]

67. Nzakizwanayo, J.; Hanin, A.; Alves, D.R.; McCutcheon, B.; Dedi, C.; Salvage, J.; Knox, K.; Stewart, B.; Metcalfe, A.; Clark, J.; et al. Bacteriophage Can Prevent Encrustation and Blockage of Urinary Catheters by Proteus mirabilis. Antimicrob. Agents Chemother. 2016, 60, 1530-1536. [CrossRef]

68. Pires, D.P.; Oliveira, H.; Melo, L.; Sillankorva, S.; Azeredo, J. Bacteriophage-encoded depolymerases: Their diversity and biotechnological applications. Appl. Microbiol. Biotechnol. 2016, 100, 2141-2151. [CrossRef] [PubMed]

69. Latka, A.; Maciejewska, B.; Majkowska-Skrobek, G.; Briers, Y.; Drulis-Kawa, Z. Bacteriophage-encoded virion-associated enzymes to overcome the carbohydrate barriers during the infection process. Appl. Microbiol. Biotechnol. 2017, 101, 3103-3119. [CrossRef]

70. Pereira, T.C.; De Barros, P.P.; Fugisaki, L.R.d.O.; Rossoni, R.D.; Ribeiro, F.d.C.; De Menezes, R.T.; Junqueira, J.C.; Scorzoni, L. Recent Advances in the Use of Galleria mellonella Model to Study Immune Responses against Human Pathogens. J. Fungi 2018, 4, 128. [CrossRef]

71. Jeon, J.; Yong, D. Two Novel Bacteriophages Improve Survival in Galleria mellonella Infection and Mouse Acute Pneumonia Models Infected with Extensively Drug-Resistant Pseudomonas aeruginosa. Appl. Environ. Microbiol. 2019, 85, e02900-18. [CrossRef]

72. Liu, Y.; Leung, S.; Guo, Y.; Zhao, L.; Jiang, N.; Mi, L.; Li, P.; Wang, C.; Qin, Y.; Mi, Z.; et al. The Capsule Depolymerase Dpo48 Rescues Galleria mellonella and Mice From Acinetobacter baumannii Systemic Infections. Front. Microbiol. 2019, 10, 545. [CrossRef] [PubMed]

73. Chadwick, J.; Aston, W.; Ricketson, J. Further studies on the effect and role of cobra venom factor on protective immunity in Galleria mellonella: Activity in the response against Proteus mirabilis. Dev. Comp. Immunol. 1980, 4, 223-231. [CrossRef]

74. Hernandez, R.J.; Hesse, E.; Dowling, A.J.; Coyle, N.M.; Feil, E.J.; Gaze, W.H.; Vos, M. Using the wax moth larva Galleria mellonella infection model to detect emerging bacterial pathogens. PeerJ 2019, 6, e6150. [CrossRef] [PubMed]

75. Wilks, S.A.; Fader, M.J.; Keevil, C. Novel Insights into the Proteus mirabilis Crystalline Biofilm Using Real-Time Imaging. PLoS ONE 2015, 10, e0141711. [CrossRef] [PubMed]

76. Abbott, D.W.; Boraston, A.B. Structural Biology of Pectin Degradation by Enterobacteriaceae. Microbiol. Mol. Biol. Rev. 2008, 72, 301-316. [CrossRef] [PubMed]

77. Knirel, Y.A.; Perepelov, A.V.; Kondakova, A.N.; Senchenkova, S.N.; Sidorczyk, Z.; Rozalski, A.; Kaca, W. Structure and serology of O-antigens as the basis for classification of Proteus strains. Innate Immun. 2011, 17, 70-96. [CrossRef] [PubMed]

78. Greenfield, J.; Shang, X.; Luo, H.; Zhou, Y.; Heselpoth, R.D.; Nelson, D.C.; Herzberg, O. Structure and tailspike glycosidase machinery of ORF212 from E. coli O157:H7 phage CBA120 (TSP3). Sci. Rep. 2019, 9, 7349. [CrossRef]

79. Beynon, L.M.; Dumanski, A.J.; McLean, R.J.; MacLean, L.L.; Richards, J.C.; Perry, M.B. Capsule structure of Proteus mirabilis (ATCC 49565). J. Bacteriol. 1992, 174, 2172-2177. [CrossRef]

80. Dumanski, A.J.; Hedelin, H.; Edin-Liljegren, A.; Beauchemin, D.; McLean, R.J. Unique ability of the Proteus mirabilis capsule to enhance mineral growth in infectious urinary calculi. Infect. Immun. 1994, 62, 2998-3003. [CrossRef]

81. Rahman, M.M.; Guard, J.; Asokan, K.; Carlson, R.W. The structure of the capsular polysaccharide from a swarming strain of pathogenic Proteus vulgaris. Carbohydr. Res. 1997, 301, 213-220. [CrossRef]

82. Armbruster, C.E.; Mobley, H.L.T.; Pearson, M.M. Pathogenesis of Proteus mirabilis Infection. EcoSal Plus 2018, 8, 8. [CrossRef]

83. Flores-Mireles, A.L.; Walker, J.N.; Caparon, M.G.; Hultgren, S.J. Urinary tract infections: Epidemiology, mechanisms of infection and treatment options. Nat. Rev. Microbiol. 2015, 13, 269-284. [CrossRef]

84. Rahman, M.M.; Guard, J.; Asokan, K.; Hughes, C.; Carlson, R.W. The Structure of the Colony Migration Factor from Pathogenic Proteus mirabilis. J. Biol. Chem. 1999, 274, 22993-22998. [CrossRef] 
85. Torzewska, A.; Stączek, P.; Różalski, A. Crystallization of urine mineral components may depend on the chemical nature of Proteus endotoxin polysaccharides. J. Med. Microbiol. 2003, 52, 471-477. [CrossRef] [PubMed]

86. Perry, M.B.; MacLean, L.L. The structure of the polysaccharide produced by Proteus vulgaris (ATCC 49990). Carbohydr. Res. 1994, 253, 257-263. [CrossRef]

87. Chen, M.; Zhang, L.; Abdelgader, S.A.; Yu, L.; Xu, J.; Yao, H.; Lu, C.; Zhang, W. Alterations in gp37 Expand the Host Range of a T4-Like Phage. Appl. Environ. Microbiol. 2017, 83, e01576-17. [CrossRef] [PubMed]

88. Dunne, M.; Rupf, B.; Tala, M.; Qabrati, X.; Ernst, P.; Shen, Y.; Sumrall, E.; Heeb, L.; Plückthun, A.; Loessner, M.J.; et al Reprogramming Bacteriophage Host Range through Structure-Guided Design of Chimeric Receptor Binding Proteins. Cell Rep. 2019, 29, 1336-1350.e4. [CrossRef]

89. Latka, A.; Lemire, S.; Grimon, D.; Dams, D.; Maciejewska, B.; Lu, T.; Drulis-Kawa, Z.; Briers, Y. Engineering the Modular Receptor-Binding Proteins of Klebsiella Phages Switches Their Capsule Serotype Specificity. mBio 2021, 12, e00455-21. [CrossRef]

90. Oliveira, H.; Pinto, G.; Mendes, B.; Dias, O.; Hendrix, H.; Akturk, E.; Noben, J.-P.; Gawor, J.; Łobocka, M.; Lavigne, R.; et al. A Tailspike with Exopolysaccharide Depolymerase Activity from a New Providencia stuartii Phage Makes Multidrug-Resistant Bacteria Susceptible to Serum-Mediated Killing. Appl. Environ. Microbiol. 2020, 86, e00073-20. [CrossRef] 